\title{
„INNY ŚWIAT JEST MOŻLIWY”: Z GWARANTOWANĄ PRACĄ CZY Z GWARANTOWANYM DOCHODEM? PRZYPADEK MARINALEDY
}

\author{
ANgELINA Kussy, FÉlix TALEgo VÁZQuEZ
}

\begin{abstract}
Abstrakt: W niniejszym artykule przywołujemy materiał etnograficzny z badań w Marinaledzie, „antykapitalistycznej” wiosce hiszpańskiej, której przypadek zainspirował nas do podjęcia refleksji nad genealogia nowoczesnego pojęcia „pracy” i krytyki jego podstaw filozoficznoantropologicznych. Postaramy się wykazać, że projekt wioski, uznanej za praktyczną realizację hasła alterglobalistów ,inny świat jest możliwy”, opiera się na chęci wzmocnienia kondycji człowieka jako pracownika i aktora procesu „produkcji”. Zarówno dominujący w Marinaledzie dyskurs, jak i praktyki społeczne krążą wokół „pracy”, a tę - jak wynika z analizy „zgromadzonego" materiału - zwolennicy „alternatywnego” projektu rozumieja w sposób, który wykształcił się w zachodniej nowoczesności i który nie odbiega od rozumienia pracy w kapitalizmie. Pragniemy zadać pytanie o ograniczenia projektów emancypacyjnych, które nie kwestionują owego konceptu pracy i wykazać, że przyjęcie konstruktu, który zaczął formować się w czasach merkantylizmu, dojrzewał w myśli liberalnej, a następnie marksizmie, związane jest $\mathrm{z}$ kondycja podporządkowania. Dlatego w ostatniej części artykułu przedstawimy Powszechny Dochód Podstawowy jako jedno z narzędzi, które osłabiałoby związek podmiotu $z$ tak rozumiana praca, po to, aby umocnić jego związek z tym, co polityczne.
\end{abstract}

Słowa kluczowe: nowoczesne pojęcie pracy, krytyka pracy, Powszechny Dochód Podstawowy, Marinaleda, antyproduktywizm, antykapitalizm, alterglobalizm. 
(...) będę z cała powaga bronić tezy, wedle której wielka część ludzkich krzywd we współczesnym świecie bierze się z przekonania o szczególnej wartości pracy i że droga do szczęścia i dobrobytu wiedzie przez zorganizowane ograniczenie ilości wykonywanej pracy.

Bertrand Russell, Pochwała lenistwa (1932)

\section{„Utopijna” wioska w Andaluzji}

Poszukując alternatyw dla liczącego już kilka dekad systemu ekonomicznego opartego na neoliberalnych założeniach, autorzy tego artykułu za miejsce swoich badań terenowych wybrali Marinaledę ${ }^{1}$ - słynną, ,antykapitalistyczną” wioskę na południu Hiszpanii, w różnych okresach jej funkcjonowania, której alternatywny system społeczno-ekonomiczny narodził się 24 lata temu. Jednak to przede wszystkim dziś stanowić miałby dowód na to, że - jak pisała o niej prasa na całym świecie ${ }^{2}$ - „inny świat jest możliwy”.

Wioska ta miała być miejscem, w którym sprawowanie władzy nie należy do polityków i ekonomicznych „ekspertów”, lecz do jej mieszkańców, którzy decyzje o determinującej ich

\footnotetext{
${ }^{1}$ Przedstawiony w tym artykule materiał etnograficzny dotyczący Marinaledy nie został zgromadzony na potrzeby niniejszego tekstu, lecz wtórnie w nim wykorzystany. Badania Talego przeprowadzone zostały na potrzeby pracy doktorskiej (1996) o „,władzy ludu” i mesjanistycznym modelu przywództwa w Marinaledzie, a badania Kussy - do pracy magisterskiej dotyczącej hegemonicznego dyskursu wioski i jej praktyk ekonomicznych, w tym funkcji kontrolnej pracy. Oba prowadzone były podczas długotrwałego pobytu w wiosce - odpowiednio dwuletniego (1991-1993) oraz ośmiomiesięcznego (2015/2016) w oparciu o metody jakościowe. W obu przypadkach zgromadzony materiał pochodził z kilkudziesięciu pogłębionych wywiadów, sporządzonych notatek terenowych z nieformalnych rozmów, wniosków z obserwacji przestrzeni, codziennego współżycia i z uczestnictwa w lokalnych rytuałach i wydarzeniach publicznych. Dobierając rozmówców, nie dazżliśmy do reprezentatywności statystycznej, ale staraliśmy się identyfikować różne grupy aktorów zgodnie z lokalnymi podziałami politycznymi, sytuacją materialną i pozycją w strukturach władzy, a „zgromadzony” (wywołany) materiał kontrastowaliśmy z danymi pochodzącymi z innych źródeł: $z$ własnymi obserwacjami, oficjalnymi danymi dotyczącymi zatrudnienia, wysokości zasiłków i płac etc. Wywiady analizowaliśmy w sposób holistyczny: nie traktując żadnego z nich jako odrębnej jednostki do analizy, lecz jako część doświadczanej przez nas rzeczywistości terenowej i dyskursów, na które składają się nie tylko praktyki słowne, ale symboliczne i materialne, w tym lokalne rytuały, techniki dyscyplinujące, strategie marginalizacji, znajdujące się w wiosce murale, plakaty i ekonomia moralna mieszkańców. Imiona pod wywiadami, przy których brakuje nazwisk, zostały zmienione na prośbę mieszkańców, którzy prosili o anonimowość.

${ }^{2}$ W The New York Times: „Praca i brak kredytu dla wszystkich...” (25 maja 2009), w Russia Today: „Hiszpańska wioska, która nie odnotowuje kryzysu” (1 maja 2015), w The Wall Street Journal: „Komunistyczna utopia w Hiszpanii”" (24 września 2014). Dan Hancox napisał książę The Village Against the World (2013), wydaną w kilku językach, która zachęciła do odwiedzin Marinaledy turystów z całego świata, a która reklamowana była słowami: „The extraordinary story of Marinaleda proves another world isn't only possible - it already exists” („Niezwykła historia wioski Marinaleda pokazuje, że inny świat jest nie tylko możliwy, ale że już istnieje”), miała największy wkład w promocję wioski jako zrealizowanej utopii, która miałaby być odpowiedzią na postulaty ruchu alterglobalistycznego. W Polsce oprócz Le Monde Diplomatique („Eksperyment, który trwa od 35 lat”, sierpień 2013), artykuł poświęciła Marinaledzie Gazeta Wyborcza (11 września 2012) oraz Kontrast. „Miasto zwane utopią” (wrzesień 2013).
} 
życie rzeczywistości podejmują oddolnie i na bieżąco („poder popular" - władza ludu), a nie raz na cztery lata, dzięki instytucji zgromadzeń (assambleas), na których, oprócz podejmowania decyzji politycznych, w równy sposób rozdziela się pracę, aby uniknąć sytuacji, w której część społeczności ją ma, a inni pozostają bez środków do życia.

Nikt z marinaleños, czyli mieszkańców i mieszkanek, nie był zmuszony do wzięcia kredytu, aby mieć własny dom - dzięki systemowi budownictwa społecznego część kosztów spłacają w naturze, biorąc udział w budowie, a resztę w miesięcznych ratach wynoszących 25 euro. Domki formalnie należą do sołectwa, aby nie były dziedziczone, nie można było nimi spekulować i kumulować ich w rękach nielicznych.

Większość marinaleños znajduje zatrudnienie w fabryce przetworów i kooperatywie Humar, nastawionej na tworzenie miejsc pracy, a nie maksymalizację zysków akcjonariuszy. Z inicjatywy Juana Manuela Sanchéz Gordillo, sołtysa Marinaledy - rządzącego od pierwszych demokratycznych wyborów (1979), a więc od śmierci generała Franco przywódcy związku zawodowego SAT, stanowiącego bazę działalności aktywistycznej w regionie oraz partii CUT - zbudowano system przypominający ideę pracy gwarantowanej (PG) ${ }^{3}$; możliwy dzięki jej podziałowi, ale i pomocy państwa (gdy część mieszkańców pracuje, druga część utrzymuje się z subwencji i zasiłków, potem następuje rotacja).

O naczelnej wartości, która stoi za tak pomyślanym systemem, dowiaduje się każdy, kto odwiedza wioskę zorganizowaną wokół głównej ulicy: Alei Wolności. Sanchéza Gordillo, głównego autora tak pomyślanego systemu, jak sam mówi, inspirują idee Marksa, Chrystusa i Ghandiego. Mieszkańcami kieruje sprzeciw wobec imperializmu (herb zdobi inskrypcja „Utopia dla pokoju”) i - przynajmniej w warstwie deklaratywnej - krytyczny stosunek do kultury amerykańskiej. Staraja się aktywnie działać politycznie: wspólnie wybierają się na manifestacje do różnych miast Hiszpanii; uczestnicząc między innymi w ruchu Oburzonych (indignados), wyrażają sprzeciw wobec polityki zaciskania pasa, skutkującej cięciami wydatków na edukację, szpitale i kulturę i równoczesnego dotowania prywatnych banków z pieniędzy podatników i podatniczek.

„Zrealizowany sen o prawdziwej wspólnocie świadomych obywateli” - myśleliśmy, znając „antykapitalistyczną” wioskę z pochodzacych z różnych źródeł opowieści, które

\footnotetext{
${ }^{3}$ Ze względu na powszechność utożsamiania w codziennym języku pracy z zatrudnieniem w kapitalizmie, zdecydowaliśmy się na tłumaczenie z hiszpańskiego trabajo garantizado, czyli pracy gwarantowanej (PG), mając na myśli ten sam koncept, który w Polsce zwykło się nazywać gwarancją zatrudnienia (job guarantee). Jak zobaczymy w dalszej części tego artykułu, możliwość porównania wniosków płynących z funkcjonowania zapewnienia pracy w Marinaledzie z koncepcją PG jest istotnie ograniczona - praca w Marinaledzie jest praca nie gwarantowana, lecz „warunkową” (ograniczony dostęp do niej mają ci, którzy nie zgadzają się z oficjalną polityka). Choć, pragniemy podkreślić, PG, pozbawione krytyki kapitalistycznego konceptu pracy, również nie zapewnia „,jakiejkowiek pracy”, ale robi to obrębie konkretnego systemu i formacji ideologicznej, jaką jest kapitalizm, co nie pozostaje bez znaczenia.
} 
kształtowały nasze oczekiwania ${ }^{4}$. Po dłuższym czasie od rozpoczęcia badań etnograficznych każde z nas odniosło jednak wrażenie, że nie jest to miejsce będące alternatywą wobec świata, który znamy. Wiedzieliśmy, że projekt ten nie jest spełnieniem snu o lepszym świecie, sama intuicja nam jednak nie wystarczyła.

Jako że w centrum dyskursu i życia społecznego w Marinaledzie znajduje się „praca”, po wymianie naszych doświadczeń terenowych, postanowiliśmy przyjrzeć się jej funkcjom, a to z kolei doprowadziło nas do refleksji filozoficzno-teoretycznej dotyczącej pochodzenia konceptu pracy, tak bardzo utrwalonego w naszych zdroworozsądkowych przekonaniach, że wydającego się oczywistym, właściwym dla każdej kultury i momentu historycznego, uniwersalnym. Nasza refleksja pozwoliła nam zauważyć, że przyczyna porażki „antykapitalistycznego" projektu tkwi nie tylko w niekonsekwencji w realizacji własnych postulatów, ale i w samych założeniach filozoficznych. Chcąc stworzyć „inny świat”, architekci projektu Marinaledy przyjęli założenia „starego świata”: umieszczając w centrum życia społecznego zatrudnienie w systemie kapitalistycznym, a tym samym umożliwiając kontrolę jednych jednostek nad drugimi. Krytyka systemu została ograniczona do kilku praktyk tożsamościowych i antykapitalistycznej narracji. Głębokich założeń krytykowanego w warstwie dyskursywnej kapitalizmu nie dotknięto: walczono o „miejsca pracy”, nie poddając krytyce jej kapitalistycznego ujęcia. O jakim koncepcie pracy zatem mowa?

\section{Merkantylizm - praca dla narodu}

Pojęcia, które stanowią dziś tak zwany „system ekonomiczny”, będące głównym filarem gospodarki („praca”, „kapitał”, „dochód”, „,rynek”), rozwijały się na dość specyficznej glebie: w ramach szerszego kontekstu pojawienia się w Europie od początku XVI wieku myślenia w kategoriach państw. Najpierw w absolutyzmie, następnie w nacjonalizmie. Miało to naszym zdaniem kolosalne znaczenie. Pojęcia te powstały w czasach rywalizacji między państwami i na jej potrzeby5. Wierzono, że państwo, które chce podbijać i nie być podbite przez inne, musi posiadać korzystny bilans wymiany handlowej, co wymagało wytężonej pracy nie tylko na

\footnotetext{
4 „Za tym projektem stoi zupełnie odmienna filozofia człowieka” - mówiła mi na początku listopada 2015 roku, pochodząca z wioski oddalonej o $14 \mathrm{~km}$ od Marinaledy, Isabell Guerra Naruda, niegdyś doktorantka Enrique Dussela (czołowego przedstawiciela krytycznej wobec klasycznej myśli europejskiej filozofii wyzwolenia), która zbiegiem okoliczności podwoziła mnie autostopem, kiedy jechałam do Marinaledy po raz pierwszy (AK). Drugiego dnia mojego pobytu w Marinaledzie wybrałem się na obrady zgromadzenia i ujrzałem około 300 osób: mężczyzn, kobiet (w latach dziewięćdziesiątych wykluczanie kobiet z działalność politycznej było powszechne w Andaluzji - przyp. autorów), w tym matek z dziećmi, starców i młodych. Nie miałem wtedy wątpliwości, że wylądowałem w miejscu prawdziwej samorządności obywatelskiej (FT).

${ }^{5}$ Wyraża to słynna teza Karla Polanyiego (2010) o tym, że gospodarka wolnorynkowa nie powstała sama z siebie, a została stworzona przez państwo i niemożliwe jest jej istnienie bez niego. Analizy merkantylizmu jako istotnego elementu w procesie ukształtowania się nowoczesnego państwa dokonał Max Weber (2002, 1015).
} 
potrzeby samych mieszkańców danego terytorium. Logika, mająca w tle rachunek geopolityczny, stanowi punkt styczności najbardziej wpływowych autorów merkantylistycznych i kontynuowana jest przez tak zwanych fizjokratów, aż do myśli Adama Smitha, który tworzy propozycje „ekonomii politycznej” ukierunkowanej na wzrost „,bogactwa narodu", co w praktyce oznaczać miało bezpieczeństwo narodowe i dobrobyt Państwa, co w założeniu tej tradycji myślenia - miałoby być tożsame z dobrobytem społeczeństwa.

Państwowo-narodowy cel, który przyświecał ekonomistom politycznym ${ }^{6}$, rzadko zauważany jest przez historyków idei ekonomicznych. Autorzy zajmujący się merkantylizmem i ekonomia polityczną postrzegali życie i dobra ludzi zamieszkujących państwa, obojętnie czy to królestwa, czy republiki, przez pryzmat szczególnego horyzontu: „wolności” narodu od zagrożeń ze strony innych państw i wolności do ich podbojów. Podmiotem ich rozważań nie był nigdy dobrostan człowieka czy obywatela, lecz „narodu”. Smith wyraźnie pisze o tym na samym wstępie Badań nad prayyczynami bogactwa narodów:

Roczna praca każdego narodu jest funduszem, który zaopatruje go we wszystkie rzeczy konieczne i przydatne w życiu, jakie ten naród rocznie konsumuje, a które stanowią bądź bezpośredni wytwór jego pracy, bądź też to, co nabywa za ten wytwór od innych narodów.

Zależnie więc od tego, czy ten produkt - lub to, co się zań nabywa - jest większy lub mniejszy w stosunku do liczby tych, którzy go mają konsumować, naród będzie lepiej lub gorzej zaopatrzony we wszystkie rzeczy konieczne i przydatne, których potrzebuje (Smith 2012, 3).

Ekonomiści polityczni bronili wolności do działań na rynku dlatego, że służyć miało to wyższemu dobru narodowemu. Instrumentalna koncepcja jednostki szokuje w jednej z czołowych debat, w którą zaangażowani byli niektórzy z nich: na temat „użyteczności biedy”. Jedni uczestnicy tej debaty ${ }^{7}$ bronili stanowiska, że biednych powinno utrzymywać się na granicy nędzy, jako że jest to najlepsza metoda, aby uciekając przed głodem, wykonywali swoja pracę starannie. Inni bronili zalet „motywującej pracy” i konieczności dostarczenia odpowiednich środków, aby robotnicy pełni optymizmu sami skłaniali się ku wydajności w swoich pełnych wysiłku i monotonii zajęciach. Bernard de Mandeville wyraził to w Bajce o pszczołach, kluczowym dziele liberalizmu ekonomicznego ${ }^{8}$ :

(...) aby odpowiednio zarządzać biednym, należy zarówno dążyć do tego, by nie cierpiał głodu, jak i uniemożliwiać mu zarobienie tyle, żeby mógł zaoszczędzić. Interes wszystkich

\footnotetext{
${ }^{6}$ Biorąc pod uwagę rachunek geopolityczny jako wspólną myśl przewodnią merkantylistów, fizjokratów oraz ekonomistów politycznych, można ich wszystkich wspólnie zaliczyć do tradycji „ekonomii politycznej”, bo przenoszą zainteresowanie ze „sztuki administrowania domem” (gr. oikonomia), która zajmowała np. filozofów klasycznych, na pole administrowania społecznością polityczną („,bogactwo narodów”).

${ }^{7}$ Bardzo szczegółowo na temat opinii o biedzie poszczególnych teoretyków merkantylizmu i liberalizmu piszą między innymi Albert Hirschman (1977), John G.A. Pocock, (1985) oraz Eric Hobsbawm (2015).

8 Tezę Mandeville'a, jakoby wady prywatne miałyby być zaletami w sferze publicznej, podziwiał choćby Friedrich Hayek (1968), jeden z ojców neoliberalizmu.
} 
bogatych narodów tkwi w tym, aby większa część biednych nie mogła pozbyć się zmartwień i aby wydawała na bieżąco to, co zarabia (za: Díez 2001, 88).

Ekonomiczny dobrobyt narodu zależy od istnienia dużej liczby ludzi, którzy są zadowoleni z ciężkiej całodziennej pracy (...). Edukacja biednych grozi pozbawieniem narodu ich produktywności. Godziny spędzone przez biednych nad książkami to czas stracony dla społeczeństwa (Mandeville 1924, 288; podkr. - AK, FV).

Na przestrzeni XVIII wieku stopniowo upowszechniała się teza, że wysokie zarobki obywateli pozytywnie wpływają na bogactwo państwa, korzystne jest więc wspieranie rozwoju rynku krajowego i promocja burżuazyjnego modelu życia nastawionego na konsumpcję. Zgodnie z tą linią argumentacyjną ekonomiści polityczni bronili dobrodziejstw nowego rodzaju luksusu: luksusu „użytecznego”, „komfortu” (przeciwstawiając go „bezużytecznemu luksusowi”, ostentacji, charakterystycznych dla szlachty). Umiarkowanie, według Mandeville’a, „zubaża” naród, uniemożliwia rozwój nauki i sztuki, pozostawiając go na łasce potężniejszych sąsiadów $(1984,164)$.

Niezależnie od sposobu argumentacji, szczegółowych opinie i linii sporu, wszyscy ekonomiści polityczni, którzy zabrali głos w debacie, postrzegali zarobki robotników i dochody kapitalistów jako środek do wyższego celu, jakim jest dobrobyt państwa: „sprawnie prosperujące przedsiębiorstwa” składać się miały na „sprawnie prosperujący naród”.

Przedzałożeniem argumentacji tej tradycji intelektualnej był radykalny instrumentalizm: człowiek miał stanowić narzędzie tworzenia narodowego splendoru. Ten rodzaj rozumowania można dostrzec już u Mandeville'a, ale to interpretacja myśli Smitha dokonana przez zwolenników liberalizmu ekonomicznego prawdopodobnie w największym stopniu wpłynęła na współczesny sposób rozumienia ekonomii i utrwalenie się przekonania, że dbałość o prywatny interes ekonomiczny jednostki, dzięki „zasadom rynku”, prowadzi do dobrobytu wspólnoty (prawo niewidzialnej ręki) (2012).

\section{Praca „produkcyjna”}

W kontekście instrumentalizującej etyki, w której człowiek nie jest celem samym w sobie, ale narzędziem dla wyższych celów, krzepła zarówno redukcjonistyczna idea dobrobytu sprowadzonego do rzeczy materialnych, jak i koncepcja pracy. Założyciele „dyscypliny

\footnotetext{
${ }^{9}$ Artykuł z języka hiszpańskiego przetłumaczyła Kussy. Tłumaczenia z j. angielskiego i hiszpańskiego z niepolskojęzycznych źródeł są również jej autorstwa.
} 
naukowej ekonomii" wierzyli w coś, co wcześniej było nie do pomyślenia: że jakakolwiek rzecz może być stworzona („wyprodukowana”) i pomnażać się ${ }^{10}$ (oraz że ludzkość tym właśnie od zawsze się zajmowała).

Wierząc, że człowiek może stworzyć coś z niczego lub z czegoś coś więcej, ekonomiści zajęli się szukaniem przyczyn tego „wzrostu” czy „produkcji”. Ze względu na decydujący wpływ książki Smitha na współczesne wyobrażenia, skupimy się na tym, jak właśnie on wyjaśniał te czynniki. Smith stworzył hierarchię aktywności ludzkich. Tych onirycznych, afektywnych, symbolicznych, lingwistycznych i tak dalej, które nie oddziałują na środowisko i przedmioty (lub oddziałuja w nieznacznym stopniu) nie postrzega jako pracy ${ }^{11}$. Na druga, wyższą kategorię składaja się aktywności, które nazywa praca i wyróżnia wśród nich te „nieprodukcyjne” i „produkcyjne” (Smith 1984, 65-85) ${ }^{12}$. Jedynie suma tych ostatnich „tworzy” bogactwo narodu.

Koncept „pracy produkcyjnej” zakłada zupełnie nową konceptualizację ludzkich aktywności i odmienny sposób myślenia o całości czynności związanych z obróbką i przekształcaniem: wcześniej wyróżniano różne zajęcia, prace i zawody, o różnych charakterystykach, niestałych celach i o różnej renomie, niemożliwych do zestawienia ze sobą ${ }^{13}$.

\footnotetext{
${ }^{10}$ Smith przeją myślenie o pracy od fizjokratów. De Mirabeau, jeden z nich, pracę dzielił na ,jałową” oraz „produkcyjną", twierdząc, iż różnica między nimi jest „taka sama jak różnica między cięciem kamienia a wytwarzaniem kamienia” (za: Arendt 2010, 110). Do dziś utrzymujący się przesąd o możliwości „stworzenia” czegoś z niczego prawdopodobnie swoja ,wiarygodność" zawdzięcza stojącej za nim metaforze naturalnej płodności życia (Arendt 2010, 130; Naredo 1995, 75). Przed XVII wiekiem nie istniało podobne przekonanie wyrażone w pojęciu ,produkcji” w znaczeniu, w którym rozwijało się ono na przestrzeni tego wieku w Europie. Uważano, że człowiek nie może wyprodukować czy stworzyć niczego, gdyż taką moc posiada wyłącznie Bóg, a istoty ludzkie moga jedynie przywłaszczać sobie stworzone bogactwa i co najwyżej przenosić je, rozwijać lub transformować w celu uczynienia z nich lepszego pożytku. Według Naredo przekonanie o „wzroście” ekonomicznym jako zjawisku samo w sobie progresywnym wzięło się z wierzeń alchemików $(1995,82)$. Aldous Huxley uważał, że to dominujące w zachodniej nowoczesności przekonanie - wbrew doświadczeniu własnemu i ludzi z innych kultur - jest dowodem na ślepa arogancję, którą Grecy nazywali hybris i spodziewali się za nią kary: Nemesis (Huxley 2004, 104).

${ }^{11}$ Wszechobecna dziś filozofia oparta na Badaniach Smitha, przesuwa zainteresowanie człowieka z relacji między ludźmi a naturą lub Bogiem na relacje ludzi z rzeczami lub z ludźmi w celu uzyskania jakichś rzeczy. Niezgodę na taką ,fałszywą antropologię" wyrażali między innymi: Kropotkin w słynnej dysertacji o znaczeniu pomocy wzajemnej dla rozwoju człowieczeństwa (2006), Ruskin w twierdzeniu, że bogactwo to nie pieniądze, a życie (2002, 70), Mauss, który pokazał, że wartość daru w innych kulturach nie zawierała się w jego „wartości wymiennej”, ale w wierze, że jest łącznikiem między osobą obdarowywaną i tą, która obdarowuje (1973) czy Fromm, który w nadawaniu przez ludzi czy społeczeństwa priorytetu rzeczom dostrzegł prowadzący do destrukcji rodzaj perwersyjnej nekrofilii (1999).

${ }^{12}$ W Badaniach Smith, mając na myśli „pracę produkcyjną”, często pisze po prostu „praca” tak, jakby czynności „,nieprodukcyjne" w zasadzie na to miano nie zasługiwały. Ale sam filozof nawet czynności, które nie były w jego systemie „pracą", nie uważał za nieważne, poświęcił im bowiem Teorie uczuć moralnych (1989). W późniejszej literaturze ekonomicznej znajdujemy jednak już tylko pojęcie „pracy” czy „produkcji”.

${ }^{13}$ Nowa klasyfikacja aktywności ludzkich wymazuje więź podmiotu z jego zawodem i redukuje całość ludzkich czynności do ich wkładu we wspólny roczny fundusz narodu (PKB) (Díez 2001, 55). Podobnie jak przemiana rzeczy i działań w towary i założenie, że możliwe jest zmierzenie ich w identyczny sposób, konstrukcja teoretyczna Smitha zakładała abstrakcyjną redukcję znaczenia. Kolosalne konsekwencje, jakie miał dla Zachodu ten zabieg, omawia Baudrillard (1972).
} 
Wraz z klasyfikacją Smitha wszystkie one zostały zredukowane do tej samej kategorii „pracy” (,produkcyjnej”) i wyniesione do wyższej kategorii względem jakichkolwiek innych ludzkich aktywności.

Według tego rozumowania, aby coś miało wartość rynkowa (pieniężna), musi mieć względną trwałość. Koncepcja ta zakłada, że siła oraz ludzka działalność są wcielone w przetwarzane rzeczy (co tworzy „kapitał”). Surowce i energia nieludzka, dzięki którym zrobione sa te rzeczy, postrzegane sa jako fundusz czy środek bezwładny i praktycznie nieograniczony, a ich wartość jako zerowa. Po przetworzeniu rzeczy zawierają zahibernowana energię i talent ludzki, które będzie można „zaktualizować” lub ponownie ulokować w przyszłych aktywnościach ludzkich, w spirali bogacenia się, czyli „,wzrostu” (Díez 2001, 4850). Filozofia Smitha tworzy nowy sens transcendencji oraz połączenia świata żywych i umarłych. W zasadzie, w miarę jak koncepcja ta stawała się dominująca, praca i kapitał zyskały aurę, którą w innych kulturach otoczone było wszystko to, co odpowiadało za mediację ze sferą transcendentną ${ }^{14}$.

Nawet krytyka pojęć Smitha i Davida Ricardo, jakiej dokonuje Karol Marks w Praycsynku do krytyki ekonomii politycznej (1953) w Prsycsynku do krytyki ekonomii politycznej (1953), nie jest krytyka, która stanowczo odchodziłaby od konceptu „pracy produkcyjnej” i dlatego nie został on odrzucony przez większość jego kontynuatorów - co nie pozostało bez znaczenia dla rozwoju produktywizmu i kultu pracy ${ }^{15}$. Marks do konceptu pracy Smitha doda1 jednak kwestie nowe. Pisal:

Ludzi można odróżnić od zwierząt ze względu na świadomość, religię albo na cokolwiek się zresztą zechce. Sami oni poczynają się [jednak] od zwierząt odróżniać gdy tylko zaczynają wytwarzać środki do życia - krok uwarunkowany ich organizacją cielesna. Wytwarzając środki do życia, wytwarzają ludzie pośrednio samo swoje życie materialne (Marks 1977, 21).

Oraz:

\footnotetext{
${ }^{14} \mathrm{O}$ tym, że wraz z nastaniem kapitalizmu praca stała się środkiem zapewniającym boską łaskę, pisał Weber (2010, 67-111). Binswanger (1994) uważa, że człowiek, który wierzy w niekończący się wzrost gospodarczy, zgadza się z ideą absolutu, a za pragnieniem akumulacji dóbr stoi ludzkie pragnienie nieśmiertelności.

${ }^{15}$ Warto przywołać dla kontrastu idee marksistów autonomistycznych. Jak pisze Weeks (2011, ze wstępu): „Odmowa pracy, koncept zaczerpnięty z marksizmu autonomistycznego, pomoże nakierować analizę na kwestie znaczenia i wartości pracy. W przeciwieństwie do innych typów marksizmu, ograniczających krytykę kapitalizmu do wyzysku i alienacji pracy bez jednoczesnej refleksji nad jej przewartościowaniem, tradycja ta dostarcza szerszego modelu krytyki, zmierzającego do zakwestionowania zarówno kapitalistycznej produkcji, jak kapitalistycznego (i socjalistycznego) produktywizmu".
} 
Podobnie jak człowiek dziki, tak też człowiek cywilizowany musi walczyć z natura, aby zaspokoić swoje potrzeby, aby zachować i reprodukować swój gatunek, a musi to czynić we wszystkich formach społeczeństwa i przy wszystkich możliwych sposobach produkcji. Wraz z jego rozwojem rozszerza się królestwo konieczności przyrodniczej, wzrastaja bowiem potrzeby; zarazem jednak wzrastają siły wytwórcze, które owe potrzeby zaspokajaja. (...) Zawsze jednak jest to królestwo konieczności. Poza jego granicami rozpoczyna się rozwój sił ludzkich jako cel sam w sobie, prawdziwe królestwo wolności. Może ono wszakże rozkwitnąć jedynie na swej niezbędnej bazie, która stanowi królestwo konieczności (Marks 1984, 560-561).

Z cytatów tych wyłania się powszechne dziś wyobrażenie o tym, że ludzkość oraz człowiek dojrzewają za pomoca pracy. Praca („społeczne stosunki produkcji”) oraz konieczność („siły produkcyjne”) sa dialektycznie splecione, niczym stała historii, zapewniaja „rozwój sił produkcyjnych”. W systemie Marksa istotne miejsce zajmuje pojęcie konieczności (tłumaczone również jako potrzeba). Był on przekonany, że wolność przyjdzie wraz z jej przezwyciężeniem, co, biorąc pod uwagę jego radykalny uniwersalistyczny historycyzm, nie przypadnie w udziale jednostce, lecz ludzkości na skutek dialektycznego procesu, w którym konieczność/potrzeba jest podziemną, metaboliczną i fundamentalną siła, która pobudza rozwój.

Dialektyczne rozumowanie, które przenika twórczość Marksa, a którego zmartwieniem była ludzka wolność, zrodziło sprzeczności w istocie dla owego celu zgubne:

a) alienacja, której Marks poświęcił Rękopisy filozoficzno-ekonomicz̨ne, jest nieszczęściem konkretnego człowieka zmuszonego do pracy w produkcji na wielką skalę, ale dobra lub konieczna dla procesu dojrzewania do wolności abstrakcyjnych: „człowieka” i „ludzkości” (Marks 1981);

b) wyzysk, wynikający z nadwyżki dochodów, którą kapitalista nie dzieli się z pracownikami w kapitalistycznym systemie produkcji, jest okradaniem ich, ale równocześnie jest paliwem napędowym historii, dlatego, że podsyca „sprzeczności klasowe”: siłę, która doprowadzi do ostatecznego socjalizmu (Marks 1968, 2013).

Z opisanych powyżej względów - i pomijając inne różnice między konceptem pracy u Smitha i u Marksa16 (z których najbardziej podstawowa to fakt, że Smith przypisywał pracy

16 Jak wyjaśnia Cleaver, mimo tych różnic, Marks przejął pojęcie pracy z filozofii i ekonomii politycznej swojego czasu (2007). Przez długi czas teoria marksistowska dokonywała za Engelsem (i ze względu na opis pracy w Kapitale) rozróżnienia między praca „,work”, który to termin miałby opisywać „pracę w ogóle” oraz „labour”, która miałaby się odnosić do pracy w kapitalizmie. Jednak, jako że praca w ogóle jest pojęciem kapitalistycznym, a wcześniej różnorodne czynności ludzkie nie były określane tym terminem, ten błąd metodologiczny narzucania na przeszłe czasy ówczesnej kategorii przyczynił się do wyobrażenia o pracy jako o uniwersalium ludzkim i tym samym utwierdzenia przekonania o jej konieczności. Uważamy za Cleaverem, że dla współczesnej myśli emancypacyjnej niezbędne jest przekroczenie antropocentrycznej terminologii marksistowskiej odnoszącej się do pracy i poszerzenie myślenia o niej o krytykę z feministycznej i ekologicznej perspektywy. 
negatywna konotację, w przeciwieństwie do Marksa) - zarówno u jednego, jak i drugiego pracakonieczność zyskują status siły wręcz prometejskiej. I to właśnie ten sposób myślenia - do którego wrócimy w dalszej części tego artykułu - stanowi założenie obecnego systemu instytucjonalnego: poprzez pracę ku wolności, czyli, co jest tym samym, wyobrażenie o wolności jako dialektycznym rezultacie konieczności ${ }^{17}$.

\section{Praca w (anty)kapitalistycznej wiosce}

Od takiego postrzegania pracy nie jest wolny również „antykapitalistyczny” projekt Marinaledy. Jej gospodarka, jako że „nie jest samotną wyspą” - jak tłumaczą jej mieszkańcy, gdy dostrzegaja niespójności w sposobie realizacji swoich postulatów - chociaż dyskursywnie odrzuca kapitalizm, nigdy nie przestała być gospodarką kapitalistyczna; rozumianą w sposób niemodelowy, bo silnie wsparta przez subwencje państwowe i filary istniejącego wciąż - choć uszczuplanego w duchu zaleceń polityki neoliberalnej - państwa dobrobytu, a także nieesencjalistyczny: jako że kapitalizm w modelowej postaci po prostu nie istnieje. Zawsze przenika się z innymi formami ekonomicznego działania, a wyobrażenie o jego „wszechobecności” i samowystarczalności jest fantazja ignorujących tę różnorodność liberałów (Gibson i Graham 1996, 260).

Podobnie rzecz się ma z wpływem w Marinaledzie dominującej globalnie kultury, o której Herbert Marcuse pisał niegdyś jako o produkującej „łatwo manipulowalne jednostki” w poświęconym analizie ideologii społeczeństwa przemysłowego Człowieku jednowymiarowym (1991). Chociaż napis na jednym z budynków w centrum wioski zawiera przekaz „wyłącz telewizję, włącz umysł", większość mieszkańców po pracy, jeśli nie wybiera się do baru (tylko mężczyźni), zasiada przed telewizorami, będąc biernymi konsumentami przekazu, co zapewne nie pozostaje bez skutków - kultura masowa, konsumpcjonizm i mitologizacja pracy widoczne sa w Marinaledzie w takim samym stopniu jak gdziekolwiek indziej. Specyficzne praktyki lokalne i dominujący ,antykapitalistyczny” dyskurs nie sprawiaja, że wioska pozostaje poza strefą wpływu globalnej neoliberalnej kultury „pragnień” (zob. Burszta i Kisielewski 2015).

Centrum życia w przekonanej o swej „historii sukcesu” wiosce jest rozrywka oraz praca, która - jako że wykonywana w ramach spółdzielni - ma stanowić gwarancję wolności i autonomii robotników, wyzwolonych w ten sposób od wyzysku kapitalistów. W założeniach „antykapitalistycznego” dyskursu, inspirowanego interpretacja pism Marksa przez sołtysa wioski, pozostaje pominięty fakt, iż praca w kooperatywie niekoniecznie zapewnia wolność od logiki kapitalizmu. Ziemia, która należała do księcia Infantado, a która po 12 latach protestów

\footnotetext{
${ }^{17}$ Kierujące się tą logiką związki zawodowe, które zaczęły tworzyć się w pokoleniu Marksa, łączyły się w celu poszerzania „,́́wiata pracowników”, żądając: „więcej miejsc pracy!” i przyczyniając się do jej (i ogółem „,klasy robotniczej”) mitologizacji i rzekomej konieczności.
} 
marinaleños rząd Andaluzji wykupił od niego w celu oddania jej w dzierżawę rolnikom z wioski, służy tworzeniu miejsc pracy w ramach spółdzielni poprzez wprowadzanie produkcji na wielką skalę i sprzedaży, w którym to celu rywalizuje się na „wolnym” rynku (niebawem prawdopodobnie stanie się ponadto własnością prywatną, gdyż kooperatyści pragną ją wykupić, czemu sprzeciwia się sołtys).

Produkcja w spółdzielni pracy Humar nastawiona jest na sprzedaż (głównie oleju z oliwek, bobu, papryki, karczochów) poza granicami wioski, a nie zaspakajanie potrzeb mieszkańców, a równocześnie sami mieszkańcy bardzo rzadko kupują wytwarzane przez siebie produkty, wybierając ich tańsze odpowiedniki. Pomimo niezadowolenia marinaleños z jedynego dostępnego rodzaju pracy, która wywołuje schorzenia fizyczne ${ }^{18}$, pożądaną sytuacją jest to, aby pracy było jak najwięcej. Nawet w momencie, kiedy robotnicy z Marinaledy przed kryzysem zarabiali spore sumy pieniędzy w kooperatywie, pozwalające na wygodne życie w wiosce, w której koszty utrzymania są niewielkie, ilość koniecznej do wykonania pracy przez jednostkę nie zmniejszała się w miarę zapewnienia dobrobytu ekonomicznego mieszkańcom tak, aby mogli poświęcić się oni innym aktywnościom niż mechaniczna praca (tak, jak zgodnie z „prawem Czajanowa” działo się to w tradycyjnej, przedkapitalistycznej ekonomii

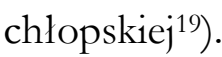

Z uwagi na swoja pracowitość klasa robotnicza, pisał w książce Andalusyjçyycy, powstańcie sołtys Marinaledy, to „pierwsi patrioci we wszystkich narodach” (Sánchez Gordillo 2013, 54). Praca stanowi centrum dyskursu i życia społecznego w Marinaledzie, która promuje się jako miejsce, w którym istnieje utopijny system społeczno-ekonomiczny, ponieważ istnieje w niej pełne zatrudnienie (co zresztą nie jest prawda). Najważniejszy w jej historii strajk promowany był jako „strajk głodowy przeciwko głodowi [pracy]” (Talego 1996, 209-215). A głównym celem samego „alternatywnego” projektu jest walka o pracę, która ma zapewniać „wolność”.

\footnotetext{
${ }^{18}$ Ciężka praca fizyczna wywołuje u wielu marinaleños silne bóle i choroby kręgosłupa. Równocześnie istnieje mocny kult pracy fizycznej. Jedna z niewielu krytyk, która pojawia się pod adresem sołtysa, dotyczy jego wykształcenia i zawodu nauczyciela historii: „nie należał nigdy do klasy robotniczej, a pretenduje do reprezentowania nas".

${ }^{19}$ Czajanow twierdził, że chłopi (w gospodarce przedkapitalistycznej, tj. przed utowarowieniem pracy) dażyli do zrównoważenia nakładu pracy i dochodu. Posiadanie pracy przez członków rodziny było celem samym w sobie, nie istniał bowiem wśród społeczności wiejskiej koncept wartości dodanej i maksymalizacji zysku rozumianych na sposób kapitalistyczny (Czajanow 1974). „Wartością dodaną” były zmaterializowane i konsumowane przez gospodarstwo dobra. Rolnik pracował tyle, ile mu wystarczyło, aby zaspokoić swoje podstawowe potrzeby, a nie dla stopy zysku: jeśli w gospodarstwie zaczynały pomagać dorosłe dzieci - rodzice odpowiednio redukowali czas pracy.
} 
AK: Myślisz, że Marinaleda posiada jakieś cele na przyszłość? Jakie to cele?

S: Myślę, że zawsze chodzi o to samo. Aby w wiosce było tyle pracy, ile się tylko da, aby wszyscy mogli mieć dom i żeby wszyscy mogli dobrze żyć . I nie byli zależni od nikogo (w. Saul, zwolennik polityki sołtysa, syn spółdzielcy).

Przedzałożeniem takiego myślenia jest przekonanie o konieczności pracy, którą należy wykonać dla wyższego celu, a nie dla zaspokojenia potrzeb własnych i bliskiej społeczności. Stąd pytania o powód niewprowadzenia jakichkolwiek elementów ekonomii alternatywnej, która mogłaby pomóc mieszkańcom w czasach, kiedy popyt na produkty z Humar się zmniejszył i nie ma wystarczająco dużo pracy do rozdzielenia ${ }^{20}$ - banków czasu, alternatywnej waluty czy choćby przestrzeni samopomocy ${ }^{21}$ - uważane są one za naiwne, a takie formy organizacji za niepoważne. Również 100 metrów kwadratowych patio w domkach socjalnych zalane jest betonem, przez co mieszkańcy nie moga posiadać nawet własnych ogródków, które mogłoby zapewnić im minimum niezależności żywieniowej i od pracy na rynku, a równocześnie jednym z tematów assambleas jest spisek wielkich koncernów (kupno Monsanto przez firmę Bayer), aby takiej niezależności społeczeństwo pozbawić.

Również praca kobiet nie jest uważana za pracę - choć status kobiety w Marinaledzie jest wyjątkowy. $\mathrm{Na}$ wiele ważnych protestów w historii wioski (np. gdy żądano od rządu doprowadzenia wody do nawadniania ziemi) zostały wysłane jedynie one. Przez sołtysa wskazywane są jako wzór do naśladowania. Wychwalane jest ich zaangażowanie w projekt, lecz pomija się nierówność płci. Kobiety w Marinaledzie pracuja bowiem przede wszystkim w domu, sprzątając i przygotowując posiłki, opiekując się dziećmi, nierzadko następnie w fabryce, a potem na rzecz „antykapitalistycznego” projektu. Są rzeczy, których nie moga robić ze względu na płeć. Nie moga pracować przy budowie domu, a gdy chca pracować na przykład przy zbieraniu oliwek, musza (taki jest warunek) dołączyć do trzyosobowej grupy, w której się pracuje, przynajmniej jednego mężczyznę. Kobiety, i tylko kobiety, przez wiele lat sprzątały instytucje publiczne w ramach pracy wolontariackiej na rzecz wspólnoty (i aby zaoszczędzić płynące na ten cel pieniądze $z$ rządu Andaluzji na potrzeby

20 „Dniówka” za dzień pracy wynosi 48 euro, im więcej osób potrzebuje zatrudnienia w spółdzielni, tym mniej moga zarobić poszczególne osoby, co przyczynia się do wzrostu niechęci wobec dzielenia jej z imigrantami (którzy przyjeżdżają skuszeni hasłem reklamowym Marinaledy: „wioska, której udało się osiagnąć pełne zatrudnienie”), a także do kłótni o pracę wśród samych mieszkańców.

${ }^{21}$ Od około 20 lat w Marinaledzie stoi pusty budynek, który miał być domem kultury (jaki istnieje w każdej innej wiosce w regionie). Niektórzy mieszkańcy uważają, że pieniądze, które rząd Andaluzji przeznaczył na ten cel, zostały wydane przez sołectwo na opłacenie autobusów, które zabierają marinaleños na antykapitalistyczne manifestacje. Budynek ten jest jednak wystarczająco wykończony, aby wykorzystać go w jakimkolwiek innym celu, czego się nie robi. Być może - niestety - dzieje się tak dlatego, że jedyną pracą, która marinaleños mogą sobie wyobrazić jako pożyteczną w ramach ustalonego horyzontu myślenia, jest ta wykonywana w ramach zatrudnienia w kapitalizmie lub praca „wolontariacka” na rzecz ,antykapitalistycznego” projektu. 
„antykapitalistycznych” akcji). A zatem niektóre z nich były odpowiedzialne za pracę w domu, na rynku oraz na rzecz Rewolucji równocześnie. Nierówność płci jest ukryta, bo to właśnie kobiety, ze względu na ich gotowość do poświęcenia, czyli morderczej pracy, są wskazywane jako „podmiot rewolucyjny”, „przodowniczki Projektu”, osoby najbardziej zaangażowane w Proces, które stanowia przykład dla innych. Feministyczna krytyka kapitalistycznego konceptu pracy dałaby się zatem zaaplikować również do przypadku „antykapitalistycznej” wioski. Niedostrzeganie pozarynkowej pracy kobiet, pracy „opiekuńczej” (Carrasco, Borderías i Torns 2011) włącza Marinaledę w teorię ekonomii politycznej, która sfery reprodukcji (Federici 2008) nie postrzega jako ekonomii (Ruiz 2012).

Różnica między praca w kapitalistycznej firmie i w Marinaledzie polega na tym, iż kooperatyści „sami są własnymi kapitalistami”22, którzy dla siebie zachowują „wartość dodatkowa", i na odmiennym rozdziale pracy. Choć nie dla akumulacji indywidualnego zysku, lecz w celu „tworzenia miejsc pracy”, żywia silne przekonanie o konieczności ciagłego „wzrostu”. Ten „wyższy” cel usprawiedliwa dehumanizująca produkcję na wielką skalę, nastawienie na wydajność i nieekologiczną (bo tańsza) uprawę. Projekt Marinaledy m.in. z powodu niespójności swoich postulatów zbliżony jest do systemu kapitalistycznego.

Domki, choć nie miały być towarem i formalnie stanowią własność sołectwa, nierzadko wynajmowane są turystom lub nowo osiedlającym się rodzinom, gdy dzierżawca emigruje, młodzi zaś wstrzymują się ze ślubem, aby indywidualnie postarać się o dom i mając dwa do dyspozycji, w jednym mieszkaja, drugi zaś wynajmują ${ }^{23}$. Marka etycznej ekonomii społecznej i zapewnienie o ekologicznej uprawie przywoływane są w nastawieniu na zysk, a nie jako kojarzone z kooperatyzmem wartości same w sobie: samorządność, autonomia, wspólna praca czy równość (do których, jako że wioska jest „zrealizowaną utopią”, już się nie dąży).

Trudno oprzeć się wrażeniu, iż w przedsiębiorstwie istnieją rażące nierówności: o ile równe prawa mają kooperatyści, którzy przez cały rok mają gwarantowaną pracę, o tyle osoby, które nie nabyły swego czasu statusu członka spółdzielni, nie tylko otrzymuja ją jedynie przez kilka miesięcy w roku, ale dodatkowo często wykonują prace wolontariackie na rzecz kooperatywy. Jako zapisani przez sołtysa, który odpowiedzialny jest za podział pracy (zgodnie z założeniami kooperatyzmu funkcję tę powinni pełnić samorządni spółdzielcy), na liście osób, które „antykapitalistyczne” prace - jak nazywany jest wolontariat - wykonali, otrzymuja następnie pierwszeństwo w otrzymaniu płatnej pracy. Praca wolontariusza ma szczególny status w Marinaledzie jako praca „moralna”, na rzecz wspólnoty, i dowód na brak

\footnotetext{
${ }^{22}$ Tymi słowami w III tomie Kapitału Marks wyraził, dlaczego uważa, że kooperatywy nie są socjalizmem jako takim, lecz „formą przejściową” (za: Jossa 2005, 3).

${ }^{23}$ Zgodnie z założeniami projektu domki te mają służyć osobom potrzebującym, dlatego gdy ktoś przestaje go potrzebować, powinna otrzymać go osoba zapisana na liście oczekujących. W praktyce traktowane są jak własność prywatna, z której indywidualne osoby czerpią zyski.
} 
charakterystycznego dla kapitalizmu egoizmu (choć najczęściej jest to dokładnie ta sama praca, np. przy zbieraniu oliwek, którą wykonuje się odpłatnie, a więc generuje ona zyski). Zachęcają do niej przekaz na sprzedawanych przy różnych okazjach koszulkach z logiem Marinaledy, z napisem „Praca wolontariacka to rewolucja” czy cytat z Jose Martíego znajdujący się w siedzibie związku zawodowego SAT, która jest także miejscem asambleas (co w symboliczny sposób „obywatela” Marinaledy zrównuje z kondycją pracownika i to tylko fizycznego, bo tych reprezentuje SAT): „Kto nie ma odwagi, aby się poświęcić, niech ma przynajmniej przyzwoitość zamilknąć przed tymi, którzy się poświęcaja”.

Praca, którą można wykonywać w ramach alternatywnego Projektu, to praca w przemyśle lub rolnictwie, ewentualnie przy budowie domów. Można otrzymać inny rodzaj zatrudnienia: w charakterze pieleggniarki czy bibliotekarza ${ }^{24}$, te miejsca pracy tworzone sa jednak przez państwo, nie są przewidziane w alternatywnym projekcie polityczno-ekonomicznym wioski, gdyż ten przewiduje jedynie produkcję na wielką skalę („dzielić ziemię to dzielić biedę” - mówi sołtys). Nieliczni drobni rolnicy i wytwórcy oraz specjaliści (tacy, jak murarze) - za wyjątkiem tych będących blisko władzy i zatrudnionych na stałe - żyją poza „,alternatywnym” systemem.

Tutaj ograniczają cię do stania przy taśmie produkcyjnej lub zbierania karczochów czy sprzątania domu na błysk. To jest ich pojęcie pracy. A więc jeśli nie zmieni się wyobrażenie o tym, nad czym trzeba pracować, to będzie dalej tak trwać i trwać... A ludzie każdego dnia bardziej zmęczeni... bardziej rozczarowani. Tutaj jest wiele pracy [wiele do zrobienia], ale najpierw trzeba zmienić przekonanie o tym, nad czym i dlaczego pracować (Ángel Traga, działacz partii Podemos, niegdyś zwolennik, dziś przeciwnik polityki sołtysa).

Kondycja człowieka w Marinaledzie, niezależnie czy spółdzielcy (mającego stała pensję), czy osób zatrudnianych dorywczo, to kondycja pracownika: pracującego przez kilka miesięcy po 8 godzin przy taśmie produkcyjnej lub 7 godzin w pełnym słońcu, dostosowującego się do rytmu hałasujących, dehumanizujących maszyn. Pozostałe miesiące w roku, będące „przerwa”” od pracy, wypełnia atmosfera nudy i marazmu, poszukiwania zatrudnienia dorywczego i ,na czarno” (w okolicznych wioskach oraz w Katalonii lub Kraju Basków). Kultura w Marinaledzie jest nieobecna ${ }^{25}$, a - zdaniem krytycznych mieszkańców i mieszkanek - niepożądana.

\footnotetext{
${ }^{24} \mathrm{Na}$ stanowisku tym pracuje znajomy sołtysa, pobierając publiczną pensję. Biblioteka pozostaje jednak zamknięta często również w godzinach jej oficjalnego otwarcia, bo nikt z niej nie korzysta.

25 Z wyjątkiem prywatnej rockowej sali koncertowej Palo Palo, której właściciel pozostaje w konflikcie z sołtysem, i omijanej przez radykalnych zwolenników Projektu, jako że propaguje „kulturę amerykańską”. Brak kultury w Marinaledzie jest szczególnie widoczny przez kontrast z położoną opodal Herrerą, wioską o długiej tradycji anarchistycznej, niewypromowanej w taki sposób jak Marinaleda, w której istnieją biblioteki, bardzo aktywna księgarnia oraz teatr.
} 
Jakiekolwiek projekty i inicjatywy muszą uzyskać zgodę na ich realizację od sołectwa, w rezultacie czego były „przetrzymywane” na biurku i nierealizowane. Krytyczni mieszkańcy dostrzegą funkcje kontrolne, jakie spełnia w społeczeństwie odcięcie od kultury i zróżnicowanych treści. Wyrażają to w hiszpańskim powiedzeniu „Daj mi chleb i mów mi głupcze”. Marinaleda wyróżnia się wśród wiosek w regionie brakiem zainteresowania edukacją. Do szkół dla dorosłych finansowanych przez państwo, z których chętnie korzysta się w wioskach obok, w Marinaledzie w 2016 roku chodziły dwie osoby.

Należy podkreślić niski wskaźnik skolaryzacji w wiosce, dużo poniżej średniej prowincji. (...) 80\% społeczności nie ukończyło szkoły podstawowej, a 36\% jest niepiśmienna: niewielu ukończyło szkołę średnią lub studia wyższe (z dokumentu przygotowanego w 2012 roku przez nauczycieli szkoły średniej im. José Saramago w Marinaledzie²ø).

Według wielu mieszkańców przyczyną tej sytuacji jest to, iż młodzież wie, że w przyszłości dostanie pracę w kooperatywie $\mathrm{i}$ dach nad głowa, i nie widzi sensu w wysiłku związanym z edukacja. Można byłoby argumentować, iż oficjalny system edukacji nie wychowuje w duchu wartości wyniesionych na sztandary w dyskursie Marinaledy, jednak przez ostatnie dekady wioskę odwiedzało wielu alternatywnych edukatorów i edukatorek pragnących stworzyć w ,antykapitalistycznej” wiosce alternatywny system nauczania. Osoby te spotykały się jednak z odrzuceniem ze strony władzy i dlatego (oraz ze względu na brak środków utrzymania) prędzej czy później opuszczały Marinaledę.

\section{Pracą mnie zniewolisz: uczestnictwo wymuszone, władza symboliczna i kontrola społeczna}

Na nakreśloną wyżej panoramę nakłada się przenikający całość życia społecznego złożony z powtarzających się haseł dyskurs (Foucault 1990) oparty na dualistycznych opozycjach: swiat „kapitalistyczny"/"alternatywny”; egoizm i indywidualizm / solidarność $i$ dobro wspólne; klasa robotniczalkapitaliści; swiat wysysku / swiat ekonomii spotecznej; bioracy udziat w Projekcie / „fachas"

\footnotetext{
${ }^{26}$ Źródło: http:/ / beramendi-enserio.blogspot.com.es/2012/08/marinaleda-el-paraiso-comunistacomo_2836.html.
} 
(faszy'sci) ${ }^{27}$; spoteczeństwa dyrygowane przez polityków i „ekspertów” ekonomicznych / spoteczeñ́stwa samorzadne i demokratycznie zarzadzane ${ }^{28}$.

Oprócz tego lokalny dyskurs posiłkujący się zaczerpniętymi z pism Marksa kategoriami takimi jak „walka klas”, „świadomość klasowa”, „wyzysk”, za którym stoi przekonanie, iż źródłem władzy jest jedynie kontrola nad środkami produkcji, inspirowany jest również anarchizmem ${ }^{29}$, choć znów w autorskiej interpretacji sołtysa redukującej go do niechęci wobec policji (której nie ma w Marinaledzie, chwalącej się tym jako dowodem na to, iż przymus nie jest potrzebny, a równocześnie przymykającej oko na liczne kradzieże i przejawy agresji wobec turystów) oraz obrazie państwa jedynie jako instytucji wspierającej kapitalizm. Wpływ tego dyskursu jest ogromny: prowadzi do ignorowania faktu, iż program budownictwa społecznego, który uważają za element własnej alternatywności względem kapitalizmu, jest finansowany z podatków, a nawet nie zdają sobie sprawy, że istnieje on - choć nie na aż tak korzystnych warunkach - również w innych wioskach w Hiszpanii. Brak wiedzy o tym, iż program ten nie jest zasługa zatajającego tę informację sołtysa, lecz elementem wsparcia terenów wiejskich przez państwo, jest o tyle szokujący, że choć Marinaleda znajduje się na terenie dość odizolowanym, mieszkańcy często odwiedzają w celach spotkań rodzinnych czy towarzyskich inne wioski.

${ }^{27}$ Zlanie się w lokalnej wyobraźni figury kapitalisty, faszysty, pana feudalnego, a nawet wyznawcy religii katolickiej, ma związek z lokalnym kontekstem historycznym. Walka klasy robotniczej z właścicielami środków produkcji oraz neoliberalnym dyskursem, będącym ideologiczną podporą klasy panującej, są w dyskursie publicznym Marinaledy jeszcze jedną odsłoną walki chłopów bezrolnych z odpowiednikami panów feudalnych (señoritos), walki „lewicy” (republikanów) z „,prawicą” (nacjonalistami wspieranymi przez Kościół) z czasów wojny domowej, a następnie opozycji wobec reżimu Franco. Można zatem powiedzieć, że jest w lokalnych wyobrażeniach uniwersalną walką ,sprawiedliwych” i grup zdominowanych z ich oprawcami. Jednak, jako że sposób walki z uciskiem oraz definicja tego ucisku sa z góry ustalone, jakakolwiek osoba, która miałaby zastrzeżenia do metod dążenia do wyzwolenia, jest utożsamiana z wrogiem.

${ }^{28}$ Dychotomie te, rzecz jasna, organizują w mniejszym lub większym stopniu imaginarium większości ludzi utożsamiających się z lewica. W Marinaledzie podziały te i skonstruowana za ich pomocą wizja świata nie inspiruja jednak dążeń i aspiracji, działań nastawionych na walkę o „lepszy i sprawiedliwszy świat”, nie wyrażają one wartości, do których należy dążý (na przykład demokratyczne zarządzanie i samostanowienie, wolność rozumiana jako brak podporządkowania jednego człowieka drugiemu), nie stanowią drogowskazów i celów działań politycznych i aktywizmu, lecz wyznaczają linie „realnie” istniejących podziałów. To znaczy są zgodnie $\mathrm{z}$ tą wizją rzeczywistości kategoriami opisowymi stanu faktycznego: $\mathrm{w}$ wyobrażeniach zaangażowanych w projekt polityczny Marinaledy osób Marinaleda jest wioską, która jest zrealizowaną utopią (o czym jest mowa w jej herbie z napisem „Utopia dla pokoju”). Na głębokim poziomie przedzałożeń wspomniane dychotomie w wyobraźni mieszkańców Marinaledy wyznaczają faktyczną granicę między „lepszym światem” (który nie tylko ,jest możliwy", lecz istnieje w Marinaledzie) a światem kapitalizmu, a jako że granica ta już jest urzeczywistniona, to należy jedynie pogłębiać działania wcześniej zaprojektowane, a demokratyczna debata wokół samych założeń nie jest pożądana. Kryzys społeczny trwający obecnie w wiosce nie jest przez to uważany za fakt ujawniający wady tkwiące w samych podstawach Projektu, lecz jest kwestia „tymczasową" i zależną od zewnętrznych czynników. Narracja o kryzysie w Marinaledzie przypomina narrację o kryzysie gospodarki kapitalistycznej, o której marinaleños mówią „to nie kryzys, to oszustwo”. Niektóre założenia dyskurs publiczny wioski podziela też z opisanym przez Strzeleckiego „modelem lirycznym” realnego socjalizmu (Strzelecki 1981).

${ }^{29} \mathrm{~W}$ rzeczywistości Marinaleda wyrasta z odmiennej tradycji niż chłopskie ruchy anarchistyczne w tym regionie, które kładły szczególny nacisk na świadomość i kulturę, a nie „walkę z biedą” (Maurice 1990). 
Ponadto tak porządkujący rzeczywistość dyskurs nie przewiduje miejsca na refleksję o tym, że w spółdzielni również mają miejsce zjawiska przeciwne ideom równości i wolności, o których mówi dominujący dyskurs, takie jak podział na kooperatywistów (którzy zawsze maja zapewnioną pracę) oraz pozostałych (którzy ustawiają się do niej w kolejce) lub podział na tych, którzy mają władzę nad słowem i wyznaczaja cele działania i tworzą „opowieść o rzeczywistości” oraz tych, którzy sa „,wykonawcami technicznymi” tych działań i biernymi odbiorcami owej ustalonej narracji. Marinaleños żywią nawet głębokie przekonanie o tym, iż „masa potrzebuje lidera” (słowo to, w zależności od kontekstu, oznacza „przywódcę”, ale równiė̇ „wodza”):

Ktoś musi sterować masą... masa nie aktywuje się sama.... I musi to być ktoś, komu ludzie ufaja. Ja nie mogę pójść do drzwi sołectwa i powiedzieć „zróbmy manifestacje”. „A ty kim jesteś?” - powiedzieliby. (...) A więc tego brakuje... bo z nim nie jest teraz najlepiej i dlatego prawdę mówiąc nie jest [tu - AK] ] najlepiej (w. Susana).

Jako że assambleas nie są w rzeczywistości demokratyczne - co najlepiej przedstawiają fragmenty wywiadów etnograficznych - nie istnieją mechanizmy naruszenia ustalonego z góry modelu działania, wniesienia własnej inicjatywy czy krytyki wykraczającej poza ów dyskurs i ramy tego, co możliwe do powiedzenia i pomyślenia.

Zgromadzenia nie powinny być miejscem, gdzie przekonuję kogoś do tego, co chcę zrobić, tylko konsultowania z ludźmi tego, co chcemy zrobić. I tego się nie robi. Teraz jest na zasadzie „opowiem ci, z czego można wybierać. Co żeśmy obmyślili. Jeśli wydaje ci się to sensowne, to fantastycznie, wrócimy wcześniej do domu, jeśli nie, to podrążymy temat, aż zacznie Ci się takim wydawać" (w. Juan Sancho - zwolennik polityki sołtysa, krytyczny wobec zgromadzeń w Marinaledzie po tym jak uczestniczył w asambleas ruchu Oburzonych).

SAT... związek demokratyczny (właściwie: asambleario), co za kłamstwo... Mówi lider i mówi lider (...). Tutaj tak jest z Gordillo, tam z Cañamero [drugi obok Sáncheza Gordillo, historyczny zwiazkowiec i lider ruchu robotniczego, dziś członek Podemos]. To nie jest demokratyczne (asambleario). Widziałem tam w Somonte [ziemia, która w 2014-2016 okupowali aktywiści z okolicznych wiosek, w tym z Marinaledy]... ludzie wierzą w okupowanie tej ziemi, wierzą w SAT, ale widzą, że coś się robi źle i nic nie mówią. Widzą i nic nie mówią. Jeśli uczestniczysz w czymś od dwudziestu lat, to jak możesz nic nie mówić, nie mieć głosu? Jak zajęli Somonte, to sołtys Palma el Río, wioski, do której przynależy ta ziemia, powiedział, że związek ma wykazać, ile miejsc pracy stworzył, gdy okupowali ziemię. Cañamero powiedział: „jak was będa pytać, ile miejsc pracy daliśmy, musicie odpowiadać, że rząd Andaluzji otrzymał miliony euro subwencji. Co zrobił z tymi pieniędzmi?”. I ludzie milczą, i później to właśnie będa 
odpowiadać. Taka to jest assamblea (w. Manolo, aktywista z Sewilli, który chciał wspomóc ekologiczną uprawę na nowo zajętej ziemi, jednak okazało się, że związek SAT wcale nie był ekologiczną uprawą zainteresowany).

\section{Demokracja na sprzedaż}

Alternatywne rozwiązania zrodziły się w Marinaledzie z antykapitalistycznych przekonań, ale i niezgody na charakterystyczne dla Andaluzji od końca XIX wieku klientelizm i rządy kacyków (caciquismo), wpływowych polityków, którzy dyktując treść debaty, a zatem wpływając na wyobraźnię i ekonomię moralną mieszkańców oraz mając władzę nad zasobami publicznymi (następnie również lokalnymi środkami przekazu i subwencjami), będąc pośrednikami pomiędzy administracją ogólnopaństwową a mieszkańcami, sprawują kontrolę społeczną we własnym interesie i dla własnego prestiżu (Alcantud 1994, 262-275) - co często ukryte zostaje za dyskursem dobra wspólnego i kolektywnej tożsamości.

Nie sposób oprzeć się wrażeniu, że w praktyce w wiosce ma miejsce reprodukcja klientelistycznego modelu, w którym obywatele rezygnuja z własnego głosu i udziału w debacie nad pożądanym kształtem, wartościami i celami wspólnoty, w zamian za to, co według ich przekonania zawdzięczają sołtysowi: pracę oraz usługi publiczne. I chociaż są wolni od „kredytu na 40 lat w kapitalizmie”, mają stałe poczucie posiadania „długu moralnego”:

\footnotetext{
On [sołtys] jest niekonsekwentny... i do tego nie możesz mówić, bo musisz dziękować, że masz pracę. Oczywiście, że dziękuję, że mam pracę. Jest dużo ludzi, którzy jej nie maja.... (...). Ja to ciężko przeszłam, bo miałam małe dziecko... a zatem bałam się walczyć [o swoje prawa pracownicze]. Inni się postawili, ale ja się bałam stracić pracę. Nigdy nie zapomnę, jak mi powiedział [Sánchez Gordillo]: „to jest to, co jest, jak chcesz, to bierzesz, jak nie, to nie”. Czułam, że zrobił mi się taki „węzeł” w gardle.... on mówi, że ja mam mu dziękować, że mam pracę... powiedziałam mu, że ma mi dziękować, że pracuję (w. María, pielęgniarka zajmująca się opieką nad osobami starszymi).
}

Konieczność posiadania pracy i domu dla normalnej egzystencji w społeczeństwie jest powodem - i skutecznym narzędziem - wymuszenia uczestnictwa w projekcie, na którego kształt uczestniczacy w nim nie mają rzeczywistego, lecz jedynie iluzoryczny wpływ. Jako że $\mathrm{w}$ regionie nie jest obecnie łatwo o pracę, a do tego otrzymanie zasiłku, a więc dochodu przez resztę roku zależy od posiadania minimum przepracowanych dni, zależność od zatrudnienia w kooperatywie dla większości mieszkańców i ich rodzin jest warunkiem przetrwania, co odsłania podstawową funkcje - funkcję kontrolna - jaką sprawuje tak zaprojektowana praca zarówno w społeczeństwach bliższych modelowi kapitalistycznemu, jak i w Marinaledzie. Zatrudnienie na „wolnym” rynku jest tą koniecznością, która zmusza do poddania się 
symbolicznej władzy ${ }^{30}$. Również redystrybucja pracy - i sama decyzja o tym, jakiego rodzaju miejsca pracy zostaną utworzone - leży w Marinaledzie w gestii sołtysa (w kapitalizmie w gestii klas uprzywilejowanych). Posiadanie pracy w danym systemie zależne jest też od faktu internalizacji dominującej ideologii, w obrębie której tworzy się takie, a nie inne miejsca pracy. W przypadku Marinaledy widoczne jest to w bardzo jaskrawy sposób, gdyż jest ona niejednokrotnie przydzielana w autobusach powrotnych $\mathrm{z}$ antykapitalistycznych manifestacji:

\begin{abstract}
- I jeśli chodzi o pracę... ludzie na to narzekają bo rozdziela się ją na „luchas” (akcjach). Z kolei lepszą pracę daje się komuś, kto może mieć wpływy, żeby ta osoba była zadowolona, gdy zaczyna sprawiać problemy. Używa się pracy, bo się wie, że ludzie jej potrzebują. I na tym się gra. Pracę dają jak ludzie przychodzą i się zapisują... Ale tematy, idee, projekty... to wszystko powinno iść osobno! Kto chce uczestniczyć, to uczestniczy, a kto nie, to nie. To jak z panem feudalnym... idę do niego, bo daje mi pracę. Muszę jeździć w jakieś miejsca... To jest brak szacunku do ludzi, grać na tym, co jest niezbędnym minimum: praca, a więc jedzenie, które ludzie muszą przynieść dzieciom do domu. To jest trochę to samo, co krytykujemy w prawicy, ale robimy tutaj to samo... (w. Libertad Sanchéz Gordillo, córka sołtysa).
\end{abstract}

Konieczność posiadania pracy zmusza marineloños do uczestnictwa w projekcie, na którego kształt nie mają wpływu. Nie moga w trakcie poddać go rewizji, przemyśleć jego celów i stojących za nim wartości na nowo (czyli brać udziału w życiu politycznym). Wartość jednostki mierzona jest natomiast proporcjonalnie do jej wkładu w Proces; lepszą pracę otrzymują osoby „zasłużone” przez uczestnictwo („poświęcenie”), a pracę w kooperatywie te, które po prostu nie podważają Projektu. Instrumentalne podejście do jednostek jako „budujących Projekt antykapitalistyczny” i kontrola poprzez pracę możliwa za pomoca przymusu ekonomicznego przypominającego „pracę dla narodu” w myśli merkantylistów czy pracę dla wyższej niż prawa pracownicze i prawa człowieka konieczności, jaką w dyskursie liberalnym wydaje się produkt narodowy brutto.

Proces widoczny podczas pracy w produkcji o wysokiej specjalizacji przekłada się również na życie polityczne w Marinaledzie, tak, jakby sposób organizacji pracy wytwarzał rodzaj habitusu: ludzie sprowadzeni są do łatwo wymienialnej masy oraz zachowany jest stały podział na rządzących i rządzonych. Obywatel sprowadzany jest do roli anonimowej osoby w tłumie na manifestacji, o której cel nie pyta (wsiadając do autobusu, marinaleños nierzadko nie wiedza, dokąd i po co jada), bo wierzy, że kierujący ów słuszny cel znaja. Nawet w sferze polityki mieszkańcy Marinaledy pozostaja „,pracownikami”, niemającymi wpływu na kształt

\footnotetext{
${ }^{30}$ „[K]ażda władza, której udaje się narzucić znaczenia, i to narzucić je jako uprawnione, ukrywając układy sił leżące u podstaw jej mocy (...)" (Bourdieu i Passeron 2006, 73).
} 
machiny systemu, na rzecz którego muszą pracować, a nie współtworzącymi determinującą ich życie rzeczywistość społeczną obywatelami.

\section{Społeczeństwo pracowników - krytyka nowoczesnego pojęcia pracy}

Opisany wcześniej nowoczesny koncept pracy, powstały w kontekście rywalizacji międzypaństwowej, który stworzył podstawy dla obecnego porządku instytucjonalnego, często (w tym w wypadku Marinaledy) nie zostaje poddany głębokiej krytyce w debacie nad nowym i bardziej sprawiedliwym porządkiem. Krytykowała go natomiast między innymi Hanna Arendt (2010) zwracając uwage, że stoi on w niezgodzie z fundamentalnymi cechami człowieka. Życie na płaszczyźnie pracy jest według niej zredukowane do wysiłku i odpoczynku. $\mathrm{Na}$ „świat ludzki” składaja się według filozofki trzy aktywności: „praca”, „wytwarzanie” i „działanie” (Arendt 2010, 26-27), z których najbliższa biologicznemu trwaniu jest właśnie praca, równocześnie najbardziej oddalona od aktywności politycznej.

Jako że praca możliwa jest do wykonania w wyniku jej podziału, sprawiającego, że niepotrzebne są szczególne umiejętności tych, którzy biorą w niej udział, są oni nierozróżnialni oraz w łatwy sposób wymienialni. Praca w wyniku niewykwalifikowanego podziału pracy jest radykalnie odmienna od współpracy między specjalistami czy wytwórcami, których Arendt przeciwstawia pracownikom. Wytwórcy, między innymi rzemieślnicy czy artyści, sprawuja pieczę nad całością procesu wytwórczego, w nim uaktywnia się ich zdobyta wiedza i zręczność, a przybory i narzędzia, którymi się posługuja, stanowią zwiększające ich potencjał przedłużenia ich własnych rąk i służą ich wiedzy. Inaczej jest w przypadku pracowników: ludzkie ciało i jego siła fizyczna same w sobie są instrumentem, dlatego o ile do rzemieślnika przypisane są jego narzędzia, o tyle do pracownika maszyny. Maszyny, od tych najprymitywniejszych po te najbardziej skomplikowane, nie służą aktywności pracowników, lecz są z nimi wymienne i co najwyżej to pracownik służy im, przystosowując rytm swojego ciała do rytmu maszyny.

Według filozofki rozwój przemysłu przyniósł spektakularny awans pracy, z pozycji najbardziej pogardzanej, którą odznaczała się we wszystkich wcześniejszych epokach ${ }^{31}$ do najbardziej wywyższonej, a istotny udział miało w tym procesie upowszechnienie się teorii Locke’a i Smitha, który stwierdził, że siła ludzka stanowi źródło bogactwa i produktywności. Arendt wyjaśnia, co przyczyniło się do tego, że Smith pomylił pracę (labour) z wytwórczością i zrównał je ze sobą 32 . Podział pracy wyparł staranną specjalizację i związek człowieka z jego

\footnotetext{
${ }^{31} \mathrm{Na}$ przykład Grecy wierzyli, że niewolnicy nie mogą być obywatelami właśnie z powodu ich bliskości ze światem ,pozaludzkim”, światem pracy.

32 Względna trwałość wytworzonej rzeczy, której wymaga Smith od ludzkiej aktywności, aby mogła być uznana za pracę, która tworzy „bogactwo”, nabiera sensu nie ze względu na swoją specyfikę jako istniejąca w świecie rzecz, ale ze względu na swoje masowe i niewykwalifikowane „przyłączenie się” do rocznego funduszu
} 
zawodem, których wcześniej wymagało choćby rzemieślnictwo. Tym samym produkcja dla konsumpcji wyparła homo faber (człowieka wytwórcę) na rzecz animal laborans (zwierzę robocze) i przypisanego mu bezosobowego podziału pracy. Stwierdzenie, że żyjemy w społeczeństwie konsumentów - pisała Arendt - to inny sposób, aby powiedzieć, że żyjemy w społeczeństwie pracowników, bo praca i konsumpcja są dwoma etapami tego samego procesu $(2010,152)$.

Inny myśliciel, Henry David Thoreau, już w czasach Marksa krytykował skupienie się społeczeństwa na produkcji:

\begin{abstract}
Większość luksusów i tak zwanych wygód życiowych jest nie tylko zbędna, lecz stanowi niewątpliwie przeszkodę w rozwoju duchowym ludzkości. (...) Większość kamienia tłuczonego przez naród zużywa się (...) na budowę jego grobu. A zatem naród sam grzebie się za życia. Co się tyczy piramid, to najbardziej niezwykły w nich jest fakt, że znalazło się tylu dostatecznie poniżonych ludzi, iż spędzili życie na budowaniu grobowca dla jakiegoś ambitnego cymbała (...) (Thoreau 2010, 36, 77).
\end{abstract}

Wyrażona $\mathrm{w}$ ten sposób myśl Thoreau stanowiła inspiracje dla propozycji teoretycznopolitycznych. Zorganizowaną i wyspecjalizowaną pracę ludzką pod przewodnictwem liderów Lewis Mumford nazwał „megamaszyną”. Megamaszyna, o której tu mowa, „była pod każdym względem autentyczną maszyna, tym bardziej że jej części, chociaż zbudowane z kości, nerwów i mięśni, funkcjonowały jako (...) elementy czysto mechaniczne" i zestandaryzowane, ograniczone w swej funkcji do wykonywania precyzyjnych zadań (Mumford 2012, 280). Największą maszynę ludzką w historii symbolizuja dla autora Mitu maşyny piramidy egipskie, stworzone za pomocą niewolniczej pracy, wykańczającej na nieznaną ani wcześniej, ani później skalę, którą ludzie byli w stanie znieść jedynie dzięki panującej ideologii: boskiej monarchii.

Utylitarne podejście do pracy człowieka przetrwało do czasów industrializmu ${ }^{33}$, w którym praca, zdaniem Mumforda, jest kolejną odsłona procesu zapoczątkowanego przez wielkie „osiagnięcia cywilizacyjne”, czyli projekty techniczne Egiptu i Mezopotamii, w centrum kultury stawiającego: porządek, produktywność, posłuszeństwo, podporządkowanie i destrukcję duchową (2012).

\footnotetext{
„bogactwa kolektywnego”, którego przeznaczeniem jest jego konsumpcja i dalsza inwestycja w cykl pracy. Dlatego owoce wytwórczości również traktowane są w systemie Smitha jako elementy pracy.

${ }^{33}$ Czytelnik mógłby zarzucić nam, że argumentacja, na której wspiera się artykuł, dotyczy gospodarki przemysłowej, a żyjemy w czasach postindustrializmu czy „późnego kapitalizmu”. Naszym zdaniem industrializm nie oznacza przewagi zatrudnienia w fabrykach nad zatrudnieniem w sektorze usług, lecz produkcję na wielką skalę, międzynarodową specjalizację pracy, podział na etapy wytwarzania produktów, który nie tylko nie zmniejsza się, ale coraz bardziej wzrasta. To też wiara w to, że należy działać na rzecz „wzrostu” czy „zwiększyć konsumpcję".
} 
Mumford nie zgadza się na powszechne ${ }^{34}$ postrzeganie pracy jako czynnika humanizacji i podkreśla rolę rozwoju rytuałów i języka. Komunikacja wśród społeczności prymitywnych była na wysokim poziomie, gdy narzędzia były jeszcze bardzo podstawowe. To ona odegrała, według niego, naczelną rolę w rozwoju ludzkości, a nie technologia, tworzenie coraz bardziej skomplikowanych przyborów i narzędzi. Jest to projektowana na przeszłe kultury wizja mentalności produktywistycznej, gdyż „współczesny człowiek bardziej skłania się ku rzeczom niż ku słowom” (Mumford 1969, 125), a konieczność „przezwyciężania naturalnych konieczności” jest najczęstszym usprawiedliwieniem dla dehumanizującej pracy, degradacji i wyzysku.

Teza Mumforda o tym, że wizja prymitywnego, agresywnego człowieka walczącego z nieprzyjazną naturą jest projekcją nowoczesnego społeczeństwa, była wsparta przez wielu antropologów, w tym Marshalla Sahlinsa, który wyjaśniał, że społeczeństwa zbierackomyśliwskie nie były społeczeństwami niedostatku, ale że można zdefiniować je jako „społeczeństwa dobrobytu”, w przeciwieństwie do współczesnych „społeczeństw niedoboru” (Sahlins 1974).

Paradygmat produktywistyczny wypromował, na co wskazywała Simone Weil (2015) już w latach trzydziestych, utylitarną koncepcję człowieka, w której ten - podczas gdy rozwój sił wytwórczych postępuje - ulega procesowi dehumanizacji. Sama społeczna konstrukcja oparta na produktywizmie i instrumentalizmie jest hierarchiczną „maszyną” generująca niewiedzę i brak wrażliwości, ale system ten, według Weil, która przekracza w ten sposób perspektywę Marksa, tak samo degraduje „uciskanych” jak i „uciskających”. Mumford podkreślał, że cechy psychiczne ludzi pracujących w ramach „megamaszyny” to nie tyle cierpienie czy złość, ale ogłupienie, brak wrażliwości i nieodpowiedzialność. Te same cechy Arendt uważała za podstawę „banalności zła” (1998). Mumford stwierdza: „Ludzie tworzący część megamaszyny prędzej czy później musieli stać się Eichmannami naszych czasów:

\footnotetext{
${ }^{34}$ Przemożna - i zawiązana ponad tradycyjnymi obozami ideologicznymi i politycznymi - zgoda co do tego, czym jest praca, zauważalna jest nie tylko w „zdroworozsądkowych” przekonaniach społeczeństwa, ale i wśród uczonych zajmujących się historią idei i instytucji. Pomimo świadomości, że pojęcie pracy, jakie dzisiaj znamy, nie pojawiło się w Europie przed XVIII wiekiem i że było nieznane innym kulturom, większość akademików obstaje przy tym, że nowoczesny koncept pracy jest uniwersalny. W przeciwnym wypadku, ich zdaniem, nie zakorzeniłby się w świadomości oraz języku i nie rozpowszechnił w specyficznej formacji, jaką była przednowoczesność. Badacze ci staraja się wykazać, że cała ludzkość, począwszy od paleolitu, organizowała się, aby pracować i pracowała nawet wtedy, kiedy nie miała świadomości, że pracuje. Zakładając, iż praca jest uniwersalnym środkiem zabezpieczania potrzeb, a nawet humanizacji (Anthony 1977; Habermas 1988; Gorz 1991). Archeologowie wychodząc $z$ tego założenia, skupiaja się na poszukiwaniach przyborów i narzędzi mających ilustrować tę tezę. Tak, na przykład, Gordon Childe (1979), Karl Wittfogel (1966) i Marvin Harris (1978), by sięgnąc po trzech najbardziej znanych i odmiennych w swych tezach autorów, wszyscy wspólnie przyczyniają się do projekcji na inne kultury nowoczesnego pojęcia pracy produkcyjnej. Zawsze istnieli jednak i przeciwnicy takiego myślenia o pracy. Do tej tradycji odwołuje się Mumford. Na przykład archeolog André Leroi-Gourhan, uczeń Marcela Maussa, choć przywiązywał wagę do „sekwencji operacyjnej” w prehistorii, w całości swojej twórczości prezentował holistyczną wizję ewolucji historycznej, nadając decydująca w niej rolę językowi oraz rozwojowi symboliki i sztuki.
} 
podwójnie zdegradowanymi, bo nawet pozbawionymi świadomości swojej degradacji” (1969, 288). Dla Weil podstawowym czynnikiem opresji była organizacja pracy i jej specjalizacja same w sobie:

\begin{abstract}
całkowite podporządkowanie robotnika przedsiębiorstwu i tym, którzy nim kierują opiera się na strukturze fabryki, a nie na systemie własności (...). Cała nasza cywilizacja polega na specjalizacji, pociagającej za sobą podporządkowanie tych, którzy wykonują, tym, którzy koordynują zaś na takich podwalinach można tylko organizować i udoskonalać ucisk, a nie zmniejszać go. Kapitalistyczne społeczeństwo nie tylko nie wypracowało w swoim wnętrzu materialnych warunków dla systemu wolności i równości, ale wprowadzenie takiego systemu wymaga wręcz uprzedniego przeobrażenia produkcji i kultury (Weil 2015, 28).
\end{abstract}

Bez takiej przemiany kulturowej - jak zauważa z kolei Arendt - w horyzoncie myślenia ludzi zredukowanych do pracowników to, co najbardziej ludzkie, wciąż wydawać się będzie „czynnością bezużyteczną”. Powodem skurczenia się ludzkiego doświadczenia według Arendt jest umieszczenie pracy w centralnym miejscu życia społecznego:

Wolność od pracy nie jest niczym nowym (...) wydaje się, jakby postęp naukowy i rozwój techniczny zostały jedynie wykorzystane do osiagnięcia tego, o czym wszystkie minione stulecia śniły, choć żadne nie mogło tych marzeń zrealizować. Są to jednak tylko pozory. Epoka nowożytna przyniosła teoretyczna gloryfikację pracy i zaowocowała faktycznym przekształceniem całości społeczeństwa w społeczeństwo pracujące. Spełnienie się życzenia, jak w baśniach, następuje w chwili, gdy może ono jedynie samo siebie unieważnić. Społeczeństwo pracowników ma zostać wyzwolone z okowów pracy, a nie zna już innych, wyższych i więcej znaczących czynności, w imię których warto tę wolność zdobywać. (...) Mamy przed sobą perspektywę społeczeństwa pracowników bez pracy, czyli bez jedynej aktywności, jaka im jeszcze pozostała (Arendt 2010, 22-23).

\title{
Zdetronizować pracę
}

Od kilku pokoleń zdecydowana większość społeczeństwa ma głęboko przyswojone przekonanie, że „praca czyni wolnym” (Arbeit macht frei - jak głosił napis na niemieckich obozach koncentracyjnych równocześnie będących obozami pracy) (Arbeit macht frei - jak głosił napis na niemieckich obozach koncentracyjnych równocześnie będących obozami pracy), przy równoczesnym założeniu, że pojęcie pracy tożsame jest z jej kapitalistycznym ujęciem, którego etyczne i filozoficzne założenia zdążyliśmy omówić. Myślenie w kategoriach wydajności pracy czy obietnic „tworzenia miejsc pracy”, które składają nam rządzący, a przedsiębiorcy uważają za powód ich uprzywilejowanej pozycji w społeczeństwie, ma swoje korzenie w długiej tradycji, 
zgodnie z która praca jest koniecznością, a „dobrobyt” czy „wolność” są wynikiem „rozwoju sił wytwórczych” czy „wzrostu PKB”. Jak pisał w 1930 roku John Maynard Keynes w wykładzie spisanym pod tytułem Możliwości ekonomicznne naszych wnukón (1931, 358-374), jeśli kierujemy się logiką „poprzez pracę do wolności”, dopiero za sto lat rozwój produktywności sprawi, że wnuki jego pokolenia będą mogły pracować jedynie 15 godzin tygodniowo:

Jeszcze co najmniej przez następnych sto lat musimy udawać sami przed sobą i przed innymi, że szpetota jest piękna, a piękno jest szpetne, bo szpetota jest użyteczna, a piękno nie. Chciwość, lichwa i przezorność muszą być naszymi bóstwami jeszcze przez pewien czas. Dlatego, że tylko one mogą wyprowadzić nas z tunelu potrzeb ekonomicznych do jasności dnia $(1931,372)$.

Tymczasem praca w coraz większym stopniu staje się centrum naszego życia. Choć to właśnie my jesteśmy wnukami pokolenia Keynesa, wciąż powtarza nam się, że dopiero na czasy naszych (znowu) wnuków przypadnie wolność w wyniku rozwoju ekonomicznego. Rozumowanie to jest podszyte omawianym wcześniej instrumentalizmem, a także wiarą, że człowiek „kiedyś” mógłby uwolnić się całkowicie od pracy (wysiłku):

Wyłącznie spowodowane prędkością postępu technicznego upojenie zrodziło szalony pogląd, że praca mogłaby pewnego dnia stać się zbędna. Na płaszczyźnie czystej nauki ten pogląd znalazł wyraz w poszukiwaniu „wiecznie poruszającej się maszyny”, czyli maszyny, która wytwarzałaby w nieskończoność pracę, a nigdy by jej nie zużywała (Weil 2015, 28).

Konieczność ponoszenia pewnego rodzaju wysiłków towarzyszyła człowiekowi zawsze i będzie towarzyszyć nawet w czasach kiedy większość prac fizycznych wykonywać będa roboty. Współczesny człowiek, który pracę w ogóle utożsamia z pracą w kapitalizmie, myli z nią wszelkie aktywności ludzkie. Zawsze istnieć będą niemieszczące się w redukcjonistycznej teorii ekonomii klasycznej prace rozumiane jako wysiłki w celu podtrzymania „świata ludzkiego", by posłużyć się terminologia Arendt. A także prace opiekuńcze: związane z wychowywaniem, edukacja, opieką nad osobami starszymi, dziećmi i tak dalej. Jak zauważa Carmen Lizarraga: „Strach przed tym, że ludzie przestaną pracować, może pochodzić jedynie z uwewnętrznienia dualistycznej koncepcji produkcja-reprodukcja, ze strachu, że przestaniemy 
produkować"35. Ekonomistka z partii Podemos ${ }^{36}$ jest zwolenniczką Powszechnego Dochodu Podstawowego ${ }^{37}$, za którego wprowadzeniem będziemy argumentować.

Praca, jak staraliśmy się wykazać w tym artykule, jest konstruktem społecznym, samo jej wydzielenie z całości aktywności ludzkich wiąże się z rozwojem kapitalizmu, a to, czy „istnieje”, zależy od tego, jak ją definiujemy, zaś zdefiniowana w sposób stanowiący filar paradygmatu produktywistycznego ma degradujący wpływ na społeczeństwo oraz funkcję kontrolną ${ }^{38}$. Dlatego projekt nowego społeczeństwa, które powstać miałoby po trwającym kryzysie - aby rzeczywiście był „nowy”, a nie stanowił przykład ,jeszcze raz tego samego” musi, w naszym przekonaniu - skupić się nie na „krytyce kapitalizmu z pozycji pracy” (i tym samym pogłębianiu jej gloryfikacji, jak dzieje się to w przypadku Pracy gwarantowanej czy w założeniach takich projektów jak ten w Marinaledzie), lecz na „krytyce pracy w kapitalizmie” (Postone 1996, 5; za: Weeks 2011, 15) i redukcji ilości wykonywanej pracy w ramach kapitalizmu w celu zapewnienia autonomii jednostkom i uwolnienia od reżimu logiki rynkowej części aktywności niezbędnych dla prawidłowego funkcjonowania demokracji. Narzędziem przybliżającym do tego celu jest, naszym zdaniem, idea PDP, która nie wiąże się ze spadkiem,

\footnotetext{
35 http:/ / www.granadadigital.es/renta-basica-universal-de-lo-inevitable-a-lo-posible-y-iii/.

36 Podczas pisania tego artykułu partia nowej lewicy, która wyrosła na fali ruchu Oburzonych, Podemos, wsparła wniosek parlamentarny PSOE („starej” lewicy) o przyspieszenie podpisania umowy o budowie pięciu korwet wojennych dla Arabii Saudyjskiej (przypominamy, iż partia ta do pierwszych wyborów szła z postulatem PDP, a ostatnio dyskusja wokół PDP znów się ożywiła). Jeden z liderów Podemos w Andaluzji, José María González Santos, burmistrz miasta Kadyks, w którym panuje wysokie bezrobocie i w którym ma mieć miejsce produkcja korwet wojennych, w artykule pod tytułem Zakładnicy bezrobocia a ofiary wojny na łamach El País (27 lutego 2017) wyraził swoją solidarność z robotnikami, którzy będą tworzyć „maszyny do zabijania”, argumentując, że dziś nie znajdują się oni w uprzywilejowanej sytuacji odmowy pracy, jak niegdyś chilijscy robotnicy, którzy w 1977 roku odmówili naprawy miejsca tortur Pinocheta. Udział w przemyśle wojennym usprawiedliwiony został koniecznym „tworzeniem miejsc pracy”. Współautor tego artykułu skrytykował tę argumentację w liście otwartym do burmistrza (ElPaís, 17 marca 2017), a Emma Martín, inna antropolożka z tego samego uniwersytetu, dokonała krytyki Talego (El País, 20 marca 2017), wyrażając przekonanie, iż nie można z uprzywilejowanej pozycji, bo będąc zatrudnionymi na uniwersytecie, wymagać solidarności od tych, którzy nie moga jej wykazać.
}

Kontrowersyjna etycznie sprzeczność, w jaką popadła „nowa” lewica, ma związek z konceptem pracy, który omawiamy w tym artykule (a więc i z kondycją człowieka w kapitalizmie, w którym mamy bardzo ograniczone możliwości etycznego działania). Omówione w tym tekście rozumienie pracy ma swój bezpośredni udział w istnieniu imperializmu i przemysłu wojennego, bowiem umacnia przekonanie, że praca jest „konieczna”, a więc można zawiesić etykę, aby ją otrzymać. O PDP myślimy jako o narzędziu osłabiającym „konieczność” pracy w ramach kapitalizmu, a zatem wzmacniającym również wolność jednostki do nieuczestniczenia w nieetycznych przedsięwzięciach i dającym możliwość wyrażenia solidarności, której - jak pisała Martín i burmistrz Kadyksu - nie mają dziś robotnicy.

${ }^{37}$ Kwestii Powszechnego Dochodu Podstawowego Praktyka Teoretycźna poświęciła cały numer 2(12)/2014, http://numery.praktykateoretyczna.pl/PT_nr12_2014_Dochod_podstawowy/PT12_2014_Dochod_podstawo wy.pdf.

38 „Pojęcie pracy w kapitalizmie oznacza nie tyle po prostu proces pracy, co również nieustanne podporządkowanie coraz większej części ludzkich działań produkcji towarowej i tym samym organizację społeczeństwa poprzez pracę" (Cleaver 2007). 
rzekomym lub realnym, liczby miejsc pracy. Jej tłem politycznym jest tradycja republikańska ${ }^{39}$ (Marczewski 2014). Dlatego cel stanowi wyposażenie obywateli i obywatelek w narzędzia pozwalające im uczestniczyć w życiu politycznym bez względu na ich status materialny. Z tym, że republikanizm wychodzi z odmiennego przeświadczenia o tym, czym jest bieda, niż to utrwalone obecnie, które rozumie ją jako ,nieposiadanie rzeczy”, niedostatek materialny (co w latach siedemdziesiątych poruszało Sáncheza Gordillo, który zdecydował wtedy, jak mówi, „poświęcić się sprawie biednych” i stworzyć alternatywny projekt Marinaledy). Z tego wyobrażenia wynika bowiem kolejne: że praca, która zapewnia pieniądze, powinna znajdować się w centrum życia człowieka (powinien on kształcić się do pracy, pracować lub zaświadczyć, że pracować nie może, aby uzyskać zasiłek). W republikanizmie zaś bieda to podporządkowanie, służalczość i zależność od innych. Natomiast bogactwo to nie jedynie dobrobyt materialny, lecz dominacja i władza nad innymi. Z tej niematerialistycznej, nieproduktywistycznej i antyautorytarnej perspektywy o danym społeczeństwie świadczy to, czy jest oparte na opozycji dominujący-zdominowani czy też na zrównoważonej współzależności (życie skromne nie jest bieda).

Dlatego też PDP nie jest „bardziej rozwiniętym” rodzajem istniejących warunkowych zasiłków, za których ideą stoi zależność społeczeństwa od rynku pracy, co wzmacnia jej centralną pozycję. Przeciwnie, jego celem jest zmniejszenie czy relatywizacja podległości względem pracy na rynku, za którym stoi fundamentalne republikańskie przekonanie, że ten, kto zależy od innych (od tych, którzy zatrudniają, od tych, którzy posiadają dostęp do zasobów materialnych), nie jest wolny. Celem PDP jest wyposażenie członków całej społeczności politycznej równocześnie w niezbędne minimum, dlatego że ci, którzy sa go pozbawieni, tracą autonomię i pozostają na łasce innych. Na PDP wsparta byłaby wolność, która może mieć miejsce jedynie między równymi (jeśli chodzi o posiadanie głosu, nie o tak zwany „poziom życia"): dlatego że wolność w republikanizmie jest z natury społeczna, a przestrzeń wolności jest tym większa dla wszystkich, im mniejsza jest przestrzeń dominacji i podporządkowania.

Według starej tradycji republikańskiej w regionie, w którym znajduje się Marinaleda, wolność osiagali równi sobie, drobni właściciele ziemscy, którzy mogli się sami utrzymać.

\footnotetext{
${ }^{39}$ Zainteresowanie propozycją minimalnej renty obywatelskiej dojrzewa w Europie od lat sześćdziesiątych XX wieku (Ovejero 1995; Parijs 2006) wraz z rozwojem nowych ruchów społecznych, nieraz komplementarnych, innym razem przeciwnych tradycyjnym żądaniom pracowniczym i narodowym. Całość idei związanych ze wzmocnieniem tego, co Habermas i inni nazywają „demokracją deliberatywną" (Habermas 2007, 143 n.) stanowiły podporę dla tej propozycji, która ma na celu zakończenie „uśpienia” obywateli, o którym pisał Marcuse (1991). Zaczątki PDP można jednak dostrzec u XIX-wiecznych przedstawicieli republikanizmu. Na przykład u Thomasa Paine’a, który twierdził, że republika to wspólnota polityczna aktywnych i uczestniczących obywateli (a nie pracowników), którzy posiadają niezbędne minimalne środki do tego i podzielają wspólne wartości. Dlatego bronił progresywnego podatku, który wyposażyłby państwo w odpowiednie środki, aby przekazać je najbardziej ich potrzebującym, nie mając na uwadze ich dobrobytu materialnego, lecz zabezpieczenie ich autonomii niezbędnej dla kompetencji politycznej (Vanderborght i Van Parijs 2005, 12). M.in. o republikańskich korzeniach idei PDP opowiada Raventós w wywiadzie dla Praketyki Teoretycźnej (Raventós 2014).
} 
Zdanie to podzielał nawet Blas Infante (1885-1936), autor słów hymnu Andaluzji, w którym śpiewa się: „Andaluzyjczycy, powstańcie, żądajcie ziemi i wolności” (to do tych słów odnosi się tytuł książki sołtysa Marinaledy) i autorytet zwolenników nacjonalizmu andaluzyjskiego (z którym utożsamiają się marinaleños). Był on obrońcą reformy agrarnej, która skończyłaby z latyfundiami i rozdzieliła ziemię tak, aby istniały tylko małej i średniej wielkości gospodarstwa niezależnych właścicieli: wspólnota „równych”. Po rewolucji rosyjskiej w Andaluzji zaczęły triumfować jednak hasła komunistyczne i inna idea reformy agrarnej: kolektywizacji ziemi w celu uprawy na wielką skalę i zakazu własności prywatnej (Malefakis 1971; Maurice 1990; Ortí 1984). Projekt Marinaledy jest spadkobiercą tej myśli, przeciwnej zarówno republikańskiej idei podziału ziemi, jak i ideom chłopskich ruchów anarchistycznych, również się za nią opowiadających, a niegdyś żywych w tym regionie.

Dla neorepublikanizmu podział ziemi w celu stworzenia społeczeństwa „równych” i „niezależnych” nie jest obecnie możliwy do utrzymania, ale propozycja PDP inspiruje się tą tradycja, żywiąc przekonanie, że minimum środków niezbędnych do życia zapewni wspólnie wypracowaną autonomię (Domènech 2004; Raventós 2007). Liderzy SAT, najbardziej liczącego się związku zawodowego w Andaluzji, tego samego, który stanowi bazę projektu Marinaledy, stanowczo opowiedzieli się przeciwko PDP. Czyżby z obawy, świadomej bądź nie, że uwolnienie od konieczności pracy w krytykowanym przez nich kapitalizmie pozbawiłoby ich równocześnie własnej władzy nad innymi?

My wierzymy, że krytyka kapitalizmu bez krytyki kapitalistycznego konceptu pracy i jego funkcji nie zapewnia głębokiej zmiany społecznej i że lepsze społeczeństwo to nie takie, które lepiej i więcej produkuje (oraz konsumuje), nawet będąc wolnym od wyzysku kapitalistów, lecz takie, które jest bardziej sprawiedliwe i wyposażone w narzędzia chroniące przed podporządkowaniem i wyzyskiem, w jakiejkolwiek postaci, i że tylko na takich podstawach możemy budować „inny świat, który jest możliwy”. 


\section{Wykaz literatury}

Alcantud, José. 1994. „El clientelismo social y político en las sociedades mediterráneas.” W Antropología. Una exploración de la diversidad humana con temas de la cultura hispana, red. Conrad Phillip Kottak. Madryt: McGraw-Hill.

Anthony, Peter D. 1977. The Ideology of Work. Londyn: Tavistock.

Arendt, Hanna. 1998. Eichmann w Jerozolimie. Ržecz o banalności z̧ła. Przeł. Adam Szostkiewicz. Kraków: Społeczny Instytut Wydawniczy ZNAK.

Arendt, Hanna. 2010. Kondycja ludzka. Warszawa: Alatheia.

Baudrillard, Jean. 1972. Pour une critique de l'économie politique du signe. Paris: Gallimard.

Binswanger, Hans Ch. 1994. Money and Magic. Critique of the Modern Economy in the Light of Goethe's „Faust”. Chicago: University Of Chicago Press.

Bourdieu, Pierre i Jean-Claude Passeron. 2006. Reprodukcja. Elementy teorii systemu nauczania. Warszawa: PWN.

Jossa, Bruno. 2005. „Marx, Marxism and the cooperative movement.” Cambridge Journal of Economics 29: 3-18.

Carrasco Cristina, Cristina Borderís i Teresa Torns. 2011. „Introducción. El trabajo

de cuidados. Antecedentes históricos y debates actuales." W El trabajo de cuidados. Historia, teoría y politicas, red. T. Torns. Madrid: La Catarata,13-98.

Childe Gordon. 1979. Los origenes de la civilización. Mexico: Fondo de Cultura Económica.

Cleaver, Harry. 2007. „Praca wciąż jest centralną kwestią”, Recykling Idei 9, wiosna/lato. http:// recyklingidei.pl/cleaver-praca-wciaz-jest-centralna-kwestia (dostęp 03.04.2017).

Czajanow, Aleksandr. 1974 (1925). La organización de la unidad económica campesina. Buenos Aires: Ediciones Nueva Visión Buenos Aires.

Díez, Fernando. 2001. Utilidad, deseo y virtud. La formación de la idea moderna de trabajo. Barcelona: Península.

Domènech, Antoni. 2004. El eclipse de la fraternidad. Una revisión republicana de la tradición socialista. Barcelona: Crítica.

Federici, Silvia. 2013. „La reproducción de la fuerza de trabajo en la economía global y la inacabada revolución feminista." W La revolución en punto cero. Trabajo doméstico, reproducción y luchas feministas, red. Silvia Federici. Madrid: Traficantes de Sueños, 153 180.

Foucault, Michel. 1990. Porzadek dyskursu. Tłum. Michał Kozłowski. Gdańsk: Słowo/obraz terytoria.

Fromm, Erich. 1999. Anatomia ludžkiej destrukcyjności. Tłum. Jan Karłowski. Poznań: Rebis.

Gorz, Andre. 1991. La metamorfosis del trabajo. Búsqueda del sentido. Madrid: Síntesis.

Gibson-Graham J.K. 1996. The End of Capitalism (As We Knew It). A Feminist Critique of Political Economy. Cambridge, MA: Blackwell.

Habermas, Jürgen. 1988. „Política conservadora, trabajo, socialismo y utopía hoy.” W: Ensayos políticos. Barcelona: Península. 
Habermas, Jürgen. 2007. Strukturalne przeobrażenia sfery publicznej. Warszawa: Biblioteka Klasyków Filozofii.

Hancox, Dan. 2013. The Village Against the World. New York: Verso Books.

Harris, Marvin. 1978. Caníbales y reyes. Los orígenes de las culturas. Barcelona: Argos.

Hirschman, Albert. 1977. The Passions and the Interest. Political Argument for Capitalism before its Triumph. Princeton: Princeton University.

Hayek, Friedrich. 1968. Dr. Bernard Mandeville. London: British Academy.

Hobsbawm, Erick. 2015 (1964). Labouring Men. Studies in the History of Labour. London: W\&N.

Huxley, Aldous. 2004. La filosofía perenne. Barcelona: Edhasa. Polskie wydanie: 2011. Filozofia wieczysta. Kraków: Biblioteka Nowej Ziemi.

Keynes, John M. 1931. „Economic Possibilities for Our Grandchildren.” W Essays in Persuasion. London: MacMillan.

Kropotkin, Piotr. 1989 (1902). Pomoc wrajemna jako çynnik rozwoju. Poznań: Oficyna Bractwo Trojka.

Malefakis, Edward. 1971. Reforma agraria y revolución campesina en la historia del siglo XX, Barcelona: Ariel.

Mandeville, Bernard. 1924 (1714). The Fable of the Bees. Oxford: Oxford University Press.

Mandeville, Bernard. 1984 (1714). La fábula de las abejas o los vicios privados hacen la prosperidad pública. Mexico: Fondo de Cultura Económica.

Marcuse, Herbert. 1991. Człowiek jednowymiarowy. Badania nad ideologia rozwinietego spoteczeństwa przemysłowego. Tłum. Wiesław Gromczyński. Warszawa: Państwowe Wydawnictwo Naukowe.

Marczewski, Paweł. 2014. „Nie-dominacja jako niezależność socjoekonomiczna.

Neorepublikańskie argumenty za bezwarunkowym dochodem podstawowym." Praktyka Teoretyczna 2(12),

http://www.praktykateoretyczna.pl/PT_nr12_2014_Dochod_podstawowy/02.Marcze wski.pdf (dostęp: 23 lipca 2017).

Marks, Karol. 1968. Kapitał: Krytyka ekonomii politycznej, t. 1. Tłum. Paweł Hoffman, Bronisław Minc, Edward Lipiński. W Karol Marks, Fryderyk Engels. Drieła, t. 23. Warszawa: Książka i Wiedza.

Marks, Karol. 1977. Ideologia niemiecka. W Karol Marks, Fryderyk Engels. Drieła, t. 3. Warszawa: Książka i Wiedza.

Marks, Karol. 1981. Rekopisy ekonomiczno-filozoficzne z.1844 r. W Karol Marks, Fryderyk Engels. Drieła, t. 1. Warszawa: Książka i Wiedza.

Marks Karol. 1984. Kapitał, t. 3, cz. 2. Tłum. Jan Maliniak, Edward Lipiński. W Karol Marks, Fryderyk Engels. Dzieła, t. 25. Warszawa: Książka i Wiedza.

Marks, Karol. 2013. Kapitał 1.1. Rezultaty bezpośredniego procesu produkcji. Tłum. Mikołaj Ratajczak. Warszawa: PWN.

Marks, Karol. 1953. Praycsynek do kerytyki ekonomii polityčnej. Warszawa: Książka i Wiedza.

Maurice, Jacques. 1990. El anarquismo andaluz. Barcelona: Crítica. 
Mauss, Marcel. 1973 (1924). „Szkic o darze. Forma i podstawa wymiany w społeczeństwach archaicznych.” W Socjologia i antropologia. Tłum. Marcin Król, Krzysztof Pomian i Jerzy Szacki. Warszawa: KR.

Mumford, Lewis. 2012. Mit maszyny: Technika a rozwój człowieka, Tom 1. Tłum. Michał Szczubiałka. Warszawa: Wydawnictwo Naukowe PWN.

Naredo, José M. 1995. La economia en evolución: Historia y perspectivas de las categorías básicas del pensamiento economico. Madrid: Siglo XXI.

Ortí, Alfonso. 1984. „Crisis del modelo neocapitalista y reproducción del proletariado rural (represión, resurrección y agonía final de la conciencia jornalera).” W Sobre agricultores y campesinos, red. Sevilla Guzmán. Madrid: MAPA.

Ovejero, Félix 1995. El ingreso ciudadano universaly los requisitos de los proyectos emancipatorios, en Barbeito et al, Un diseño no productivista para las políticas sociales, Buenos Aires: Miño y Dávila.

Pocock, John G.A. 1985. Virtue, Commerce and History. Essays on Political Thought and History. Cambridge: Cambridge University Press.

Polanyi, Karl. 2010 (1944). Wielka transformacja, Warszawa: PWN.

Postone, Moishe. 1996. Time, Labour, and Social Domination. A Reinterpretation of Marx's Critical Theory. Cambridge: Cambridge University Press.

Raventós, Daniel. 2007. Las condiciones materiales de la libertad. Barcelona: El Viejo Topo.

Raventós, Daniel. 2014. „Dochód podstawowy w centrum uwagi w Hiszpanii”. Wywiad Macieja Szlindera. Tłum. Jakub Krzeski, Kamil Piskała. Praktyka Teoretyczna. http://www.praktykateoretyczna.pl/dochod-podstawowy-w-centrum-uwagiwhiszpanii/ (dostęp 23 lipca 2017).

Ruiz, Beatriz. 1999. „La reproducción también es economía.” Revista internacional de ciencias sociales 19: 101-116.

Ruskin, John. 2002 (1862). A este último. Cuatro ensayos sobre los principios básicos de la economía politica. Granada: Alhulia.

Sahlins, Marshall. 1974. Stone Age Economics. Piscataway: Transaction Publishers.

Sánchez Gordillo, Juan J. 2013. Marinaleda. Andaluces, levántaos. Marinaleda: Stowarzyszenie Kulturalne Ernesto Che Guevara.

Smith, Adam. 2012 (1776). Badania nad natura i praycsynami bogactwa narodów. Tłum. Stefan Wolff i Oswald Einfeld. Warszawa: Wydawnictwo Naukowe PWN.

Smith, Adam. 1984. La riqueza de la nación, t. II, ks. II, rozdz. III („De la acumulación de fondos, o del trabajo productivo y del no productivo”). Barcelona: Orbis, 65-85.

Smith, Adam. 1989 (1759). Teoria uczuć moralnych. Tłum. Stanisław Jedynak. Warszawa: PWN.

Strzelecki, Jan. 1981. „Propozycje języka lirycznego. Model socjalizmu.” Teksty 1(55): 31-54.

Talego, Félix. 1996. Cultura jornalera, poder popular y liderazgo mesiánico. Antropología política de Marinaleda. Sevilla: Fundacja Blas Infante.

Thoreau, Henry D. 2010. Walden, czyli zycie w lesie. Tłum. Halina Cieplińska. Poznań: Rebis.

Vanderborght, Yannick i Philippe van Parijs. 2005. L'allocation Universelle. Paris: La Découverte. 
Van Parijs, Philippe. 2006. La renta básica. Una medida eficazpara luchar contra la pobreza. Barcelona: Paidós.

Weber, Max, 2002 (1922). Gospodarka i społeczeństwo. Tłum. Dorota Lachowska. Warszawa: PWN.

Weber, Max. 2010. Etyka protestancka a duch kapitalizmu. Tłum. Jan Miziński. Warszawa: Alatheia.

Weil, Simone. 2015 (1934). Reflexiones sobre las causas de la libertady de la opresión social. Madrid: Trotta. Wersja polska: http://portal.tezeusz.pl/2009/07/26/iv-przemyslenia-na-tematprzyczyn-wolnosci-i-ucisku-w-spoleczenstwie/.

Weeks, Kathie. 2011. The Problem with Work. Feminism, Marxisms, Antiwork Politics, and Postwork Imaginaries. Duke University Press.

Wittfogel, Karl.1966. Despotismo oriental. Estudio comparativo del poder totalitario. Madrid: Guadarrama. 
Angelina Kussy - antropolożka skupiająca swoje zainteresowania badawcze w obrębie antropologii ekonomii i antropologii politycznej. Kształciła się na Wydziale Etnologii i Antropologii Kulturowej i w Instytucie Kultury Polskiej na Uniwersytecie Warszawskim oraz na wydziałach antropologii społecznej na uniwersytetach w Barcelonie i w Granadzie. Robiła badania etnograficzne w Andaluzji i Katalonii wśród nowych ruchów społecznych i analizowała ich dyskursy. Ostatnio interesuje ją krytyka pracy z perspektywy antropologicznej, feministycznej i ekologicznej. Tłumaczka, publicystka i aktywistka. Pisała m.in. dla Le Monde Diplomatique: edycja polska, Nowych Peryferii, Nowego Obywatela i tygodnika Przegląd.

\section{DANE ADRESOWE:}

Instytut Etnologii i Antropologii Kulturowej

Uniwersytet Warszawski

ul. Żurawia 4

00-503 Warszawa

E-MAIL: angelinakussy@gmail.com

Félix Talego Vázquez - profesor antropologii społecznej na Uniwersytecie w Sewilli, członek GEISA (grupa badawcza zajmująca się tożsamościami społeczno-kulturowymi w Andaluzji), Hiszpańskiej Sieci na Rzecz Dochodu Podstawowego i Platformy na Rzecz Dochodu Podstawowego w Sewilli. Prowadził badania dotyczące m.in. kwestii agrarnych i pracowników bezrolnych w Andaluzji, męskiej dominacji i jej związku z przemocą domową oraz tematyki uzależnień skupiając się na wierzeniach, praktykach i organizacjach pozarządowych, które zajmuja się osobami uzależnionymi. Jego ostatnie badania dotyczyły nowych ruchów społecznych, w szczególności aktywizmu ekologicznego i alterglobalizmu. Obecnie bada konflikty ekologiczne spowodowane eksploatacją złóż kopalin, koncentrując się na związkach zawodowych górników i tradycyjnym braku wrażliwości ekologicznej ruchu robotniczego.

\section{DANE ADRESOWE:}

Departamento de Antropología Social

Facultad de Geografía e Historia

Universidad de Sevilla

c/ Dona María de Padilla, s/n.

41004 Sevilla, España

E-MAIL: ftalego@us.es 
CYTOWANIE: Kussy, Angelina i Félix Talego Vázquez. 2017. „Inny świat jest możliwy”: z gwarantowana praca czy z gwarantowanym dochodem? Przypadek Marinaledy. Praktyka Teoretyczna 2(24): 68-100.

DOI: $10.14746 /$ prt.2017.2.3

\section{AUTHOR: Angelina Kussy, Félix Talego Vázquez}

TITLE: "Another world is possible": with guaranteed work or guaranteed income? Marinaleda's case

ABSTRACT: The article presents the results of two periods of long-term fieldwork in Marinaleda, an 'anti-capitalist' Spanish village. It aims to reflect on the genealogy of the modern understanding of the term 'work' and to critically approach its philosophical and anthropological assumptions. We want to prove that the proposition of the village, declared by alter-globalists as the practical realisation of the slogan 'another world is possible', is based on their striving to reinforce the condition of people as workers and actors in the 'production' process. In Marinaleda, both the prevailing discourse and social practices in fact focus on 'work'; this term however - according to the gathered ethnographic interviews and observations - remains to be understood by the supporters of the 'alternative' project in a way that has been shaped in the modern West, and is thus not any different from the definition of 'work' in capitalism. We therefore want to address the question of limits of the emancipation projects that do not challenge the concepts of 'work' and 'production'. Furthermore, we believe that adopting the construct of work that started to be formulated in the time of mercantilism and matured in the liberal and subsequently Marxist thought is related to taking a position of subordination. This is why we suggest Universal Basic Income as one of the tools that can weaken the link between the subject and such understood 'work' and consequently reinforce its political ties.

KEYWORDS: Modern concept of work, critique of labour, Universal Basic Income, anticapitalism, alter-globalization 